Check for updates

Cite this: RSC Adv., 2022, 12, 6149

Received 31st January 2022

Accepted 9th February 2022

DOI: $10.1039 / \mathrm{d} 2 \mathrm{ra00674j}$

rsc.li/rsc-advances

\section{Cu(II)-thiophene-2,5-bis(amino-alcohol) mediated asymmetric Aldol reaction and Domino Knoevenagel Michael cyclization: a new highly efficient Lewis acid catalyst $\uparrow$}

\begin{abstract}
Abdullah Mohammed Al-Majid, ${ }^{* a}$ Abdullah Saleh Alammari, ${ }^{a}$ Saeed Alshahrani, (D) a Matti Haukka, (D) ${ }^{\mathrm{b}}$ Mohammad Shahidul Islam (D) ${ }^{* a}$ and Assem Barakat (iD)

The highly efficient Lewis acid-catalytic system $\mathrm{Cu}($ (I)-thiophene-2,5-bis(amino-alcohol) has been developed for enantioselective Aldol reaction of isatin derivatives with ketones. The new catalytic system also proved to be highly enantioselective for the one pot three-component Domino Knoevenagel Michael cyclization reaction of substituted isatin with malononitrile and ethylacetoacetate. The chiral ligand (2S,2'S)-2,2'-((thiophene-2,5-diylbis(methylene))bis(azanediyl))bis(3-phenylpropan-1-ol) (L1) in combination with $\mathrm{Cu}(\mathrm{OAc})_{2} \cdot \mathrm{H}_{2} \mathrm{O}$ employed as a new Lewis acid catalyst, furnished 3-substituted-3hydroxyindolin-2-ones derivatives (3a-s) in good to excellent yields (81-99\%) with high enantioselectivities (up to $96 \%$ ee) and spiro[4H-pyran-3,3-oxindole] derivatives (6a-l) in excellent yields (89-99\%) with high ee (up to 95\%). These aldol products and spiro-oxindoles constitute a core structural motif in a large number of pharmaceutically active molecules and natural products.
\end{abstract}

\section{Introduction}

The chiral ligand-Lewis acid-metal catalysed carbon-carbon bond construction process has become increasingly interesting to synthetic chemists as well as pharmacists, for carrying out various crucial organic transformations. In particular, chiral versions of these catalytic processes are one of the prominent strategies to access several enantiopure bioactive molecules. ${ }^{1-5}$ Among them, the asymmetric Aldol reaction and Domino Knoevenagel Michael cyclization reaction are the most powerful and efficient approaches for accessing various enantiomerically enriched biomolecules. ${ }^{6,7}$

The core framework '3-alkyl-3-hydroxyindolin-2-ones' is present in a large number of natural products ${ }^{8-14}$ and drug molecules ${ }^{15-19}$ such as maremycins, ${ }^{17}$ arundaphine, ${ }^{20}$ donaxaridine,$^{21}$ paratunamide ${ }^{22},(R)$-convolutamydines $\mathrm{A}, \mathrm{B}$ and $\mathrm{E},{ }^{23-27}$ flustraminol, ${ }^{28}$ diazonamides, ${ }^{29-33}$ leptosin $\mathrm{D},{ }^{34} 3^{\prime}$ -

${ }^{a}$ Department of Chemistry, College of Science, King Saud University, P. O. Box 2455, Riyadh 11451, Saudi Arabia. E-mail: 436106737@student.ksu.edu.sa; alamary1401@yahoo.com; 436106738@student.ksu.edu.sa; chemistry99y@gmail. com; ambarakat@ksu.edu.sa; amajid@ksu.edu.sa; mislam@ksu.edu.sa; Fax: +96661-1467-5992

${ }^{b}$ Department of Chemistry, University of Jyväskylä, P. O. Box 35, FI-40014 Jyväskylä, Finland. E-mail: matti.o.haukka@jyu.fi

$\dagger$ Electronic supplementary information (ESI) available. CCDC 2143162. For ESI and crystallographic data in CIF or other electronic format see DOI: 10.1039/d2ra00674j hydroxyglucoisatisin, ${ }^{35}$ CPC-1, ${ }^{36}$ 3-hydroxy welwitindolinones C, ${ }^{37}$ TMC-95 (A-D), ${ }^{38-40}$ celogentin $\mathrm{K},{ }^{41}$ dioxibrassinin ${ }^{42}$ (Fig. 1).

Therefore, the development of efficient and practical methods to synthesize this kind of building block is of great importance and is currently an open area of research in asymmetric catalysis. ${ }^{43-45}$ A representative example has been developed recently for asymmetric Aldol reaction of ketones with

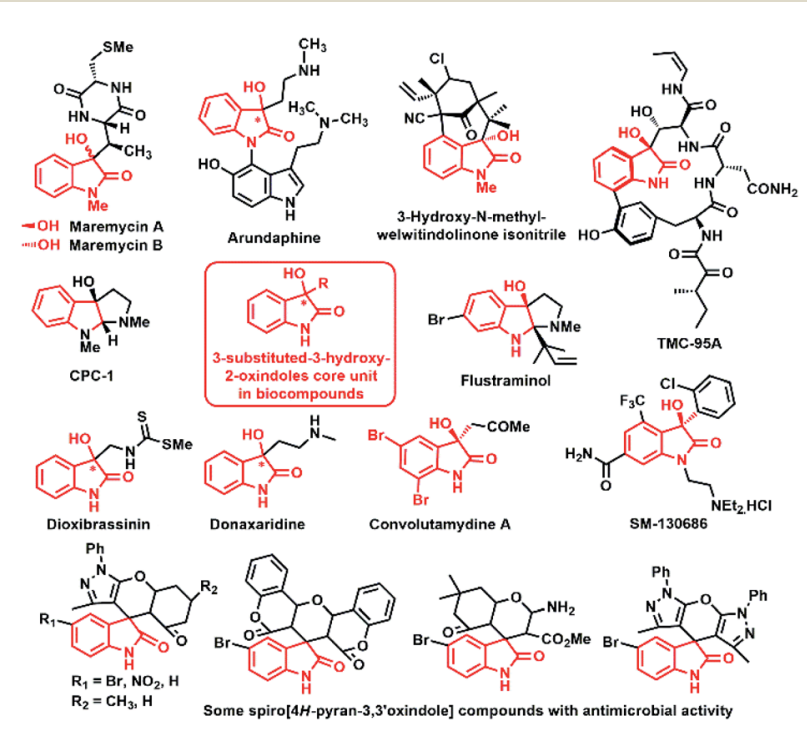

Fig. 1 Prominent bioactive compounds based 3-substituted-3hydroxy-2-oxindoles and spiro[4H-pyran-3,3'-oxindole] motifs. 
various isatins which is one of the most straightforward and powerful methods in order to achieve highly enantiopure biologically active core framework '3-alkyl-3-hydroxyindolin-2ones' with new chiral stereocenters. ${ }^{46-52}$ Ever since, proline catalysed cross-Aldol reaction of aldehydes and ketones first reported by List and Barbas in $2000,{ }^{53}$ since then, lot of chiral amine ligands have been used as organo-catalyst for the crossAldol asymmetric reaction. ${ }^{47,54}$ In 2005 , for the first time asymmetric Aldol reaction of isatin with acetone was first developed by Tomasini et al. employing dipeptide-based ligand as organocatalyst. ${ }^{55-59}$ However, significant efforts have been made for developing efficient asymmetric Aldol reactions of isatins with ketones mostly using organocatalysts such as proline, ${ }^{60-62}$ prolinamides, ${ }^{63-69}$ sulphonamides, ${ }^{70-72}$ amines, ${ }^{73,74}$ quinidine-thioureas, ${ }^{75-77}$ vicinal amino-alcohol, ${ }^{78}$ enzymes, ${ }^{79}$ 4hydroxydiarylprolinol ${ }^{80}$ and amino acid salts. ${ }^{81}$

The spiro-heterocyclic oxindoles are the eye-catching targets to the synthetic chemist and biologist because of their biological significance to a wide-range of synthetic utility such as alkaloids intermediates, drug candidates and clinical pharmaceuticals agents. ${ }^{82-89}$ In particular, 'spiro[4H-pyran-3,3'-oxindole]' moiety is the most important heterocyclic skeleton that could be found in spirooxindoles framework complex molecules of several alkaloids and drug agents. ${ }^{82,83}$ Over the couple years, sizable number of investigation have been carried out successfully for the construction of spiro[ $4 \mathrm{H}$-pyran-3,3'-oxindole] framework as a core skeleton of spirooxindole structures. ${ }^{90-92}$ Domino Knoevenagel Michael cyclization is one of the highly successful procedures for the stereoselective synthesis of spirooxindole derivatives derived spiro[ $4 H$-pyran-3, $3^{\prime}$-oxindole] moiety. ${ }^{93,94}$ To construct this interesting scaffold, Yuan and coworkers in 2010 for the first time, utilized cupreine-(60hydroxycinchonidine) as organocatalyst for accessing chiral spiro[4H-pyran-3,3'-oxindole] derivatives from multi component reactions of $\mathrm{N}$-alkylated isatins. ${ }^{95}$ Recently, Nakano et al. reported hybrid squaramide amino alcohol organo-catalyzed asymmetric Domino Michael cyclization reactions of oxoindolines with cyclic 1,3-diketones, affording chiral spiroconjugated oxindoles tethering 2-aminopyrans heterocyclic ring systems with excellent yield and enantioselectivity. ${ }^{96}$ In 2019, Swapna Konda and co-workers synthesized chiral spiro [ $4 H$-pyran-3,3'-oxindole] derivatives with good chemical yield (up to $92 \%$ ) and enantioselectivity (up to $87 \%$ ee) using cinchona alkaloid thioureas as an organocatalysts. ${ }^{97}$ However, till date very limited efforts have been made for the construction of stereoselective spiro-heterocyclic oxindole, engrafting 2amino- $4 \mathrm{H}$-pyran-3-carbonitrile ring at the $\mathrm{C}_{3}$ position of oxindole via asymmetric Domino Michael cyclization reaction.

However, very limited findings have been reported for the application of Lewis acid catalyzed asymmetric Aldol reaction ${ }^{\mathbf{9 8}}$ of ketones with isatin in order to excess derivative of '3-alkyl-3hydroxyindolin-2-ones' and asymmetric Domino Michael cyclization reaction ${ }^{99-101}$ of isatin with malononitrile and ethylacetoacetate to furnish enantiopure spiro[4H-pyran-3,3'oxindole] derivatives. Therefore, further investigations are required to produce bioactive motif like '3-alkyl-3- hydroxyindolin-2-ones' and spiro[ $4 H$-pyran-3,3'-oxindole $]$ using Lewis acid catalyst, that remains a great challenge.

Recently, a series of new chiral bis(amino-alcohol)thiophene ligands- $\mathrm{Cu}(\mathrm{OAc})_{2} \cdot \mathrm{H}_{2} \mathrm{O}$ as a Lewis acid catalytic system have been developed by our group and their catalytic application was successfully applied for enantioselective Henry reaction to afford the corresponding chiral Henry product with satisfactory yield and enantioselectivity. ${ }^{5}$ On observing their good catalytic enantioselective induction in the Henry reaction, we decided to explore the utility of those chiral ligands for different applications such as enantioselective Aldol reaction as well as Domino Michael cyclization reaction.

As per the best of our knowledge, we are reporting for the first time chiral bis(amino-alcohol)thiophene ligand-Lewis acid catalysed enantioselective Aldol reaction of isatins with substituted acetone to produce enantiopure 3-substituted-3hydroxy-2-oxindoles derivatives as well as Domino Michael cyclization reaction of isatins with malononitrile and ethylacetoacetate to afford the chiral oxindoles spiro[4H-pyran-3,3'oxindole] fused with 2-aminopyrans heterocyclic ring systems.

\section{Results and discussion}

\section{Catalytic asymmetric studies of Aldol reaction}

The following ligands as shown in Fig. 2 reported recently by our research group as an examples of $\mathrm{C}_{2}$-symmetric chiral thiophene-2,5-bis(amino-alcohol) ligands (L1-L5) and successfully applied them in catalytic asymmetric Henry reaction of nitromethane with substituted aldehydes in excellent yield and enantioselectivity (yield up to $99 \%$ and ee up to $95 \%$ ). ${ }^{5}$ (Fig. 2). We further decided to examine their asymmetric catalytic efficiency and therefore enantioselective Aldol reaction of isatin with substituted acetone as well as three-component chiral Domino Michael cyclization reaction of isatin with malononitrile and ethylacetoacetate have been explored successfully.

Initially, Aldol reaction of 5-bromoisatin (1a) with acetone (2a) as model substrate were carried out for accessing 3substituted-3-hydroxy-2-oxindoles derivatives, using $20 \mathrm{~mol} \%$ chiral thiophene-2,5-bis(amino-alcohol) ligands (L1-L5) as organocatalysts in ethanol $(2 \mathrm{~mL})$ at room temperature (rt) under inert atmosphere for $24-48 \mathrm{~h}$ and we observe that, all the ligands were found to be efficient to furnish aldol product $\mathbf{3 a}$ (89-99\% yield) in excellent yield but unfortunately failed to induce enantioselectivity (16-21\% ee) effectively (Table 1).

Then the catalytic efficacy of these ligands were examined in combination with metal salt like copper acetate monohydrate $\left(\mathrm{Cu}(\mathrm{OAc})_{2} \cdot \mathrm{H}_{2} \mathrm{O}\right)$ generated a metal complex in situ as a Lewis

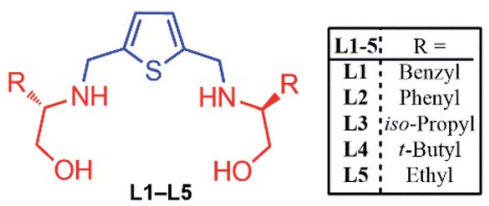

Fig. $2 \mathrm{C}_{2}$-symmetric chiral thiophene-2,5-bis(amino-alcohol) ligands (L1-L5) used for Aldol reaction and Domino Michael addition reaction. 
Table 1 Enantioselectivity Aldol reaction of 5-bromoisatin (1a) with acetone (2a) catalyzed by organocatalysts L1-L5

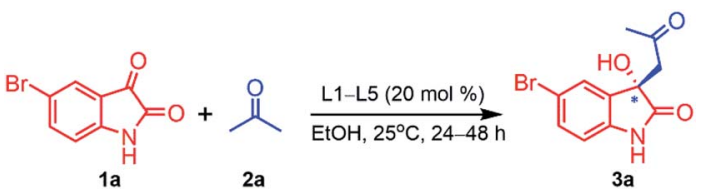

\begin{tabular}{lllll}
\hline Entries $^{a}$ & Ligands & Time (h) & Yield $^{b}(\%)$ & ee $^{c}(\%)$ \\
\hline 1 & L1 & 24 & 99 & 21 \\
2 & L2 & 24 & 99 & 16 \\
3 & L3 & 24 & 99 & 19 \\
4 & L4 & 24 & 99 & 20 \\
5 & L5 & 48 & 89 & 20
\end{tabular}

${ }^{a}$ Reactions were performed on $0.2 \mathrm{mmol}$ of isatin and $10.0 \mathrm{mmol}$ of acetone. ${ }^{b}$ Isolated yields after column purification. ${ }^{c}$ Enantiomeric excess (ee) was determined by chiral HPLC using a Daicel Chiralpak $\mathrm{AD}-\mathrm{H}(25 \mathrm{~cm} \times 4.6 \mathrm{~mm} \times 5 \mu \mathrm{m})$.

acid catalytic system for asymmetric Aldol reaction of 5-bromoisatin (1a) with acetone (2a, 50 eq.). Subsequently, the reaction was performed in ethanol $(2 \mathrm{~mL})$ at $25{ }^{\circ} \mathrm{C}$ under inert atmosphere, using $10 \mathrm{~mol} \%$ of ligands L1-L5 with $20 \mathrm{~mol} \%$ of $\mathrm{Cu}(\mathrm{OAc})_{2} \cdot \mathrm{H}_{2} \mathrm{O}$ for $24 \mathrm{~h}$ and the corresponding findings were documented in Table 2. Fortunately, all the ligands (L1-L5) were found to be capable of producing aldol product 3a with significantly enhanced enantioselectivity (44-58\% ee) (Table 2, entries 1-5) but the chemical yields were significantly dropped (44-60\%). Interestingly, ligand $\mathbf{L 1}$ and $\mathbf{L 4}$ bearing benzyl and $t$ butyl group respectively were found to be the most effective ligand in combination with $\mathrm{Cu}(\mathrm{OAc})_{2} \cdot \mathrm{H}_{2} \mathrm{O}$, furnishing highest yield (60\% and 58\%) accordingly. However, higher enantioselectivity ( $58 \%$ ee) was observed in presence of $\mathbf{L 1}$ as compared to $\mathbf{L 4}$ (48\% ee) (Table 2, entries 1 and 4 ) and therefore $\mathbf{L 1}$ has been chosen for further optimization.

Table 2 Enantioselectivity Aldol reaction of 5-bromoisatin (1a) with acetone (2a) catalyzed by ligand (L1-L5) in presence of $\mathrm{Cu}(\mathrm{OAc})_{2} \cdot \mathrm{H}_{2} \mathrm{O}$

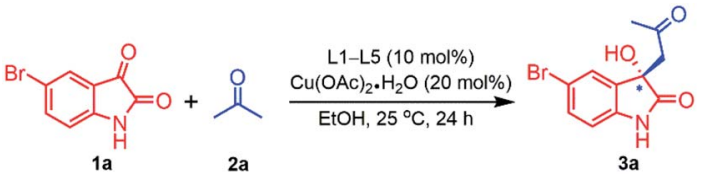

\begin{tabular}{lllll}
\hline Entries $^{a}$ & Ligands & Time (h) & Yield $^{b}(\%)$ & ee $^{c}(\%)$ \\
\hline 1 & L1 & $\mathbf{2 4}$ & $\mathbf{6 0}$ & $\mathbf{5 8}$ \\
2 & L2 & 24 & 44 & 47 \\
3 & L3 & 24 & 48 & 45 \\
4 & L4 & 24 & 58 & 48 \\
5 & L5 & 24 & 45 & 44
\end{tabular}

${ }^{a}$ Reactions were performed on $0.2 \mathrm{mmol}$ of isatin and $10.0 \mathrm{mmol}$ of acetone. ${ }^{b}$ Isolated yields after column purification. ${ }^{c}$ Enantiomeric excess (ee) was determined by chiral HPLC using a Daicel Chiralpak AD-H $(25 \mathrm{~cm} \times 4.6 \mathrm{~mm} \times 5 \mu \mathrm{m})$.
In order to improve the yield and enantioselectivity, asymmetric Aldol reaction of 5-bromoisatin (1a) with acetone (2a, 50 eq.) was further investigated. The effect of different metal salts such as $\mathrm{Cu}(\mathrm{OAc})_{2} \cdot \mathrm{H}_{2} \mathrm{O}, \mathrm{Zn}(\mathrm{OAc})_{2} \cdot 2 \mathrm{H}_{2} \mathrm{O}, \mathrm{Zn}(\mathrm{OTf})_{2}, \mathrm{Mg}(\mathrm{OTf})_{2}$, $\operatorname{Er}(\mathrm{OTf})_{3}$ and $\mathrm{Yb}(\mathrm{OTf})_{3}$ as a Lewis acid as well as various solvents system like EtOH, $\mathrm{CH}_{2} \mathrm{Cl}_{2}$, dioxane and THF were explored, using $10 \mathrm{~mol} \%$ of ligand $\mathbf{L 1}$ with $20 \mathrm{~mol} \%$ metal salts at rt over the period of $24-72 \mathrm{~h}$ and the summery of the results were shown in Table 3. It is evident from the results that, the catalytic system of $\mathbf{L 1}-\mathrm{Cu}(\mathrm{OAc})_{2} \cdot \mathrm{H}_{2} \mathrm{O}$ in solvents like $\mathrm{CH}_{2} \mathrm{Cl}_{2}$ and dioxane, improved enantiomeric excess (ee) (74\% \& 76\%) respectively as compared to ethanol (yield $60 \%$, ee $58 \%$ ) but the chemical yields were still low (58\% and 45\%) (Table 3, entries 13). However, in case of catalytic system $\mathbf{L 1}-\mathrm{Cu}(\mathrm{OAc})_{2} \cdot \mathrm{H}_{2} \mathrm{O}$ (10 : $20 \mathrm{~mol} \%$ ) in THF as solvent was found to be the best choice as Lewis acid catalyst for the asymmetric Aldol reaction of 5bromoisatin (1a) with acetone (2a, 50 eq.), furnishing the best yield and enantioselectivity (65\% yield, $82 \%$ ee) (Table 3 , entry 4). Nevertheless, L1- $\mathrm{Zn}(\mathrm{OAc})_{2} \cdot 2 \mathrm{H}_{2} \mathrm{O}$ in THF produce $50 \%$ yield with very poor enantioselectivity $(17 \%$ ee) in $72 \mathrm{~h}$ (Table 3 , entry 4). Moreover, ligand $\mathbf{L 1}$ in combination with metal salts like $\mathrm{Zn}(\mathrm{OTf})_{2}, \mathrm{Mg}(\mathrm{OTf})_{2}, \operatorname{Er}(\mathrm{OTf})_{3}$ and $\mathrm{Yb}(\mathrm{OTf})_{3}$ in THF were found to be completely ineffective for the asymmetric Aldol reaction (Table 3, entries 6-9). The poor efficiency of $\mathrm{Zn}^{+2}$ complex as compared to $\mathrm{Cu}^{+2}$ complex could be attributed to the higher electronegativity $\left[\mathrm{EN}\right.$ of $\left(\mathrm{Cu}^{2+}\right)=1.90>\mathrm{EN}$ of $\left.\left(\mathrm{Zn}^{2+}\right)=1.65\right]$ and greater charge to radius ratio of $\mathrm{Cu}^{+2}$ than $\mathrm{Zn}^{+2}$ ion, those are two factors perhaps help $\mathrm{Cu}^{2+}$ to form covalent bond with $\mathrm{O}$ and $\mathrm{N}$ atoms of ligand stronger than $\mathrm{Zn}^{2+}$ during the complex formation.

From these several attempts to achieve acceptable yield and high enantioselectivity, it can be concluded that, L1-Cu(OAc) ${ }_{2}^{-}$ $\cdot \mathrm{H}_{2} \mathrm{O}(10: 20 \mathrm{~mol} \%)$ as Lewis acid catalyst, in THF at rt for $24 \mathrm{~h}$

Table 3 Enantioselectivity Aldol reaction of 5-bromoisatin (1a) with acetone (2a); solvents and metal salt screening

\begin{tabular}{|c|c|c|c|c|c|}
\hline Entries $^{a}$ & Solvents & Metal salts & Time (h) & Yield $^{b}(\%)$ & $\mathrm{ee}^{c}(\%)$ \\
\hline 1 & EtOH & $\mathrm{Cu}(\mathrm{OAc})_{2} \cdot \mathrm{H}_{2} \mathrm{O}$ & 24 & 60 & 58 \\
\hline 2 & $\mathrm{CH}_{2} \mathrm{Cl}_{2}$ & $\mathrm{Cu}(\mathrm{OAc})_{2} \cdot \mathrm{H}_{2} \mathrm{O}$ & 24 & 58 & 74 \\
\hline 3 & Dioxane & $\mathrm{Cu}(\mathrm{OAc})_{2} \cdot \mathrm{H}_{2} \mathrm{O}$ & 24 & 45 & 76 \\
\hline 4 & THF & $\mathrm{Cu}(\mathrm{OAc})_{2} \cdot \mathrm{H}_{2} \mathrm{O}$ & 24 & 65 & 82 \\
\hline 5 & THF & $\mathrm{Zn}(\mathrm{OTf})_{2}$ & 72 & Trace & - \\
\hline 6 & THF & $\mathrm{Zn}(\mathrm{OAc})_{2} \cdot 2 \mathrm{H}_{2} \mathrm{O}$ & 72 & 50 & 17 \\
\hline 7 & THF & $\operatorname{Mg}(\mathrm{OTf})_{2}$ & 72 & - & - \\
\hline 8 & THF & $\mathrm{Yb}(\mathrm{OTf})_{3}$ & 72 & - & - \\
\hline 9 & THF & $\operatorname{Er}(\mathrm{OTf})_{3}$ & 72 & - & - \\
\hline
\end{tabular}

${ }^{a}$ Reactions were performed on $0.2 \mathrm{mmol}$ of isatin and $10.0 \mathrm{mmol}$ of acetone. ${ }^{b}$ Isolated yields after column purification. ${ }^{c}$ Enantiomeric excess (ee) was determined by chiral HPLC using a Daicel Chiralpak AD-H $(25 \mathrm{~cm} \times 4.6 \mathrm{~mm} \times 5 \mu \mathrm{m})$. 
able to afford better yield and enantioselectivity for the asymmetric Aldol reaction of 5-bromoisatin (1a) with acetone (2a, 50 eq.). However, further optimizations are required as the results were not up to the marks as far as yields and enantioselectios are concerned. Therefore, other crucial parameters such as loading of catalyst, equivalent of acetone, time variation and temperature control were further screened to obtain the best optimized condition for the asymmetric Aldol reaction.

To find out the best optimized parameters, initially Aldol reaction were performed using $5 \mathrm{~mol} \%$ and $15 \mathrm{~mol} \%$ of ligand L1 with $20 \mathrm{~mol} \%$ of $\mathrm{Cu}(\mathrm{OAc})_{2} \cdot \mathrm{H}_{2} \mathrm{O}$ in THF at $\mathrm{rt}$ for $24 \mathrm{~h}$ and it can be seen from the results that neither the yields ( $52 \%$ \& 68\%) nor enantioselectivities $(74 \%$ \& $70 \%$ ee) were improved (Table 4 , entries 1 \& 2). Then the loading of $\mathrm{Cu}(\mathrm{OAc})_{2} \cdot \mathrm{H}_{2} \mathrm{O}$ as metal salt were increased from 20 to 30 and $40 \mathrm{~mol} \%$, keeping the other parameters unchanged (10 mol\% of ligand L1 in THF at rt for 24 h). We observed that, both the corresponding yields ( $88 \%$ and $88 \%)$ as well as enantiomeric excess $(96 \%$ \& $86 \%$ ee) were improved significantly (Table 4, entries 3 \& 4), although $10: 30 \mathrm{~mol} \%$ ratio of $\mathrm{L1}-\mathrm{Cu}(\mathrm{OAc})_{2} \cdot \mathrm{H}_{2} \mathrm{O}$ was found to be the best choice for the asymmetric Aldol reaction as it has furnished the final product 3a in excellent yield and enantioselectivity (88\% yield, 96\% ee) (Table 4, entry 3). Next, may be the temperature has an impact on catalytic efficiency of this new catalytic system. Therefore, the reaction was further performed, using $10: 30 \mathrm{~mol} \%$ of $\mathbf{L 1}-\mathrm{Cu}(\mathrm{OAc})_{2} \cdot \mathrm{H}_{2} \mathrm{O}$ in THF at rt for $24 \mathrm{~h}$ at lower temperature $10{ }^{\circ} \mathrm{C}$ as well as $0{ }^{\circ} \mathrm{C}$, but unfortunately results indicated that, the yields ( $69 \%$ \& $53 \%$ ) and enantioselectivities (73\%, $71 \%$ ee) both were significantly dropped (Table 4, entries $5 \& 6)$ although prolong reaction time $(48 \mathrm{~h})$ was given. We further investigated the reaction with different molar ratio of acetone $(10,20,40,60$ eq.) under the best optimum parameters and the findings are reported in Table 4 entries $7-10$, still 50 eq. of acetone is the best choice to get better yield and enantioselectivity. From the overall investigation, we came to conclusion that, $10 \mathrm{~mol} \%$ of ligand $\mathbf{L 1}$ with $30 \mathrm{~mol} \%$ of $\mathrm{Cu}(\mathrm{OAc})_{2} \cdot \mathrm{H}_{2} \mathrm{O}$ in THF at $\mathrm{rt}$ for $24 \mathrm{~h}$ produced best result as we obtained aldol product in high yield $(88 \%)$ and enantioselectivity (96\%).

After establishing standard reaction parameters, we extended the substrate scope for the asymmetric Aldol reaction under the optimized reaction condition, using Lewis acid catalyst L1-Cu(OAc) $)_{2} \cdot \mathrm{H}_{2} \mathrm{O}(10: 30 \mathrm{~mol} \%)$ in THF at rt for $24 \mathrm{~h}$. A variety of substituted isatin (1a-l) with several acetone derivatives $(\mathbf{2 a}-\mathbf{h})$ were screened for the asymmetric Aldol reaction using optimized reaction parameter and the corresponding aldol chiral derivatives of 3-hydroxyindolin-2-one (3a-s) were obtained in good to excellent yields (81-99\%) with moderate to high enantiomeric excess $(35-96 \%$ ee) and the results are summarized in Table 5. Our optimized catalytic system worked efficiently in case of isatin derivatives bearing electron-donating groups (5-Me and $\mathrm{N}$-Me) which afforded aldol products $3 \mathbf{h}$ ( $99 \%$ yield, 93\% ee) and $3 \mathbf{j}$ ( $91 \%$ yield, $89 \%$ ee) respectively (Table 5 , entries 8 \& 10). Exceptionally, 5-bromoisatin afforded best enantioselectivity (96\% ee) and good yield ( $88 \%$ ) (Table 5 , entry 1). While, in case of isatin derivatives containing electronwithdrawing groups such as 5 -Cl, $N$-benzyl and $N$-ethylbromide, this catalytic system also worked remarkable well and afforded respective aldol products (3c, $3 \mathbf{k}$ and $3 \mathbf{l})$ with excellent yields (99\%, 91\% and $98 \%)$ and very good enantiomeric excess ( $76 \%, 78 \%$ and $71 \%$ ee) (Table 5 , entries $3,11 \& 12$ ). However, this catalytic system furnished aldol products $\mathbf{3 b}, \mathbf{3 e}, \mathbf{3 f}$ and $\mathbf{3 i}$ with very good yields $(99 \%, 99 \%, 88 \%$ and $97 \%)$ and moderate enantioselectivities ( $62 \%, 55 \%, 44 \%$ and $53 \%$ ee) when isatin, 5 methoxy, 5-nitro and 5-fluoro isatin were used as nucleophilic centre for Aldol reaction (Table 5, entries 2, 5, 6 \& 9). Noteworthy to mention that, while using 6-chloro and 5,7-dibromo isatin for the Aldol reaction, our catalytic system performed under

Table 4 Enantioselective Aldol reaction of 5-bromoisatin (1a) with acetone (2a); loading of catalyst and temperature control

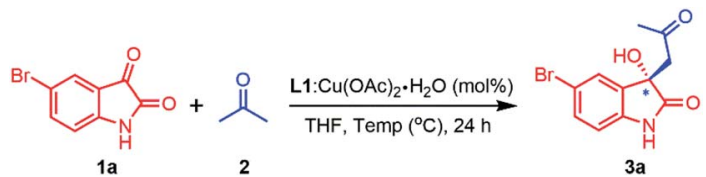

\begin{tabular}{|c|c|c|c|c|c|c|}
\hline$\#^{a}$ & $\begin{array}{l}\mathbf{L 1} / \mathrm{Cu}(\mathrm{OAc})_{2} \cdot \mathrm{H}_{2} \mathrm{O} \\
(\mathrm{mol} \%)\end{array}$ & Acetone (eq.) & Time (h) & Temp $\left({ }^{\circ} \mathrm{C}\right)$ & Yield $^{b}(\%)$ & $\mathrm{ee}^{c}(\%)$ \\
\hline 1 & $05 / 20$ & 50 & 24 & 25 & 52 & 74 \\
\hline 3 & $10 / 30$ & 50 & 24 & 25 & 88 & 96 \\
\hline 4 & $10 / 40$ & 50 & 24 & 25 & 88 & 86 \\
\hline 5 & $10 / 30$ & 50 & 48 & 10 & 69 & 73 \\
\hline 8 & $10 / 30$ & 20 & 24 & 25 & 72 & 85 \\
\hline 9 & $10 / 30$ & 40 & 24 & 25 & 79 & 86 \\
\hline 10 & $10 / 30$ & 60 & 24 & 25 & 74 & 85 \\
\hline
\end{tabular}

${ }^{a}$ Reactions were performed on a $0.2 \mathrm{mmol}$ of isatin and 10-60 eq. of acetone. ${ }^{b}$ Isolated yields after column purification. ${ }^{c}$ Enantiomeric excess (ee) was determined by chiral HPLC using a Daicel Chiralpak AD-H $(25 \mathrm{~cm} \times 4.6 \mathrm{~mm} \times 5 \mu \mathrm{m})$. 
Table $5 \mathrm{L1}-\mathrm{Cu}(\mathrm{OAc})_{2} \cdot \mathrm{H}_{2} \mathrm{O}$ catalyzed asymmetric Aldol reaction of substituted isatin (1a-l) with ketone (2a-h) under optimized reaction parameters. Proposed transition states for the final compound
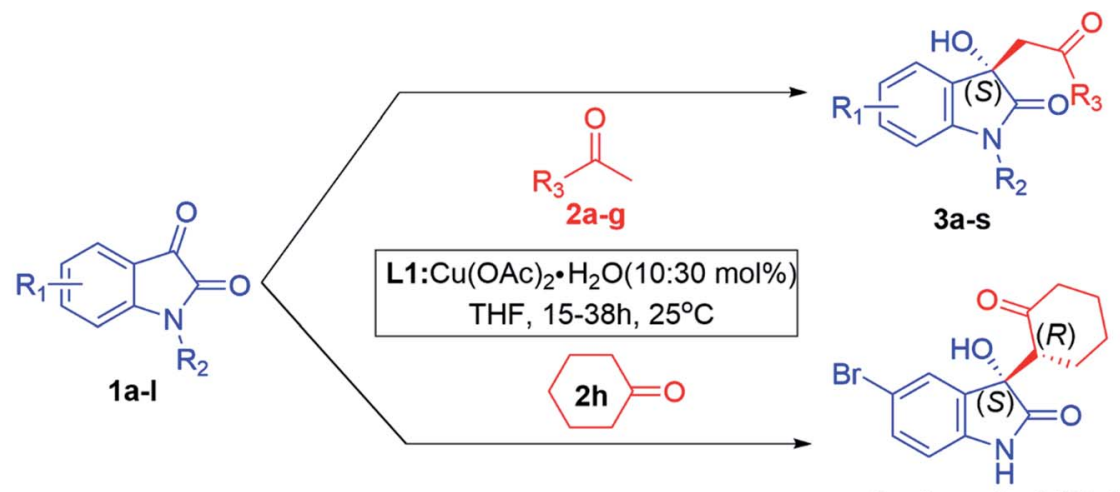

3s dr syn/anti (88:12)

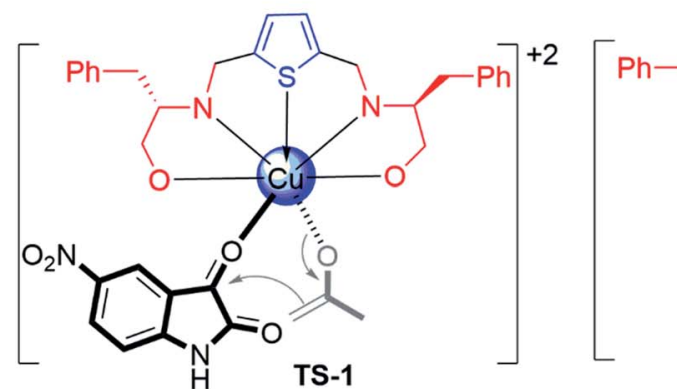

Si face favoured<smiles>CC(=O)C[C@]1(O)C(=O)Nc2ccc([N+](=O)[O-])cc21</smiles>
3f (S)-major isomer
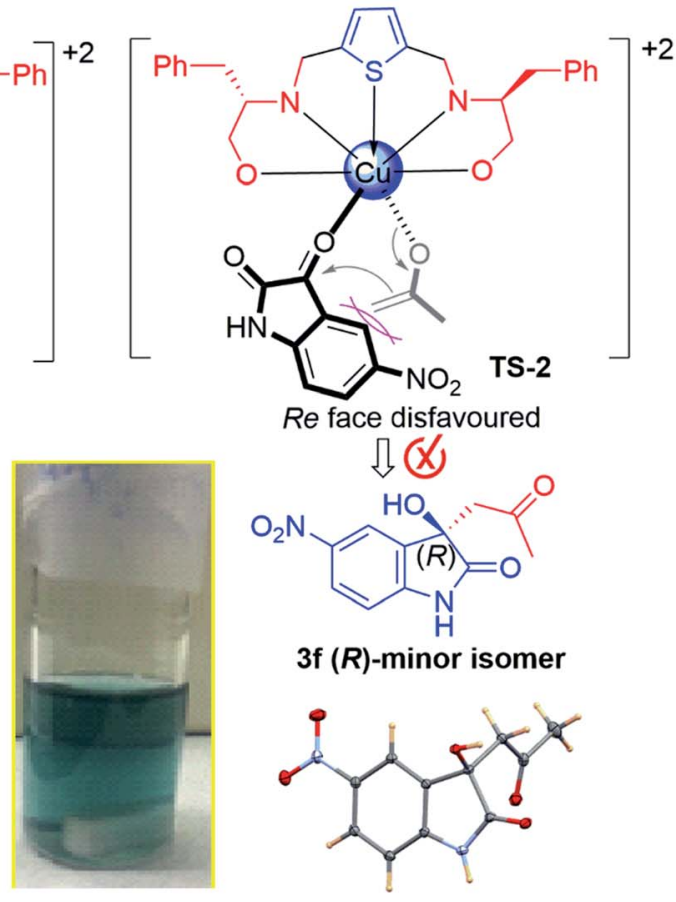

Re face disfavoured<smiles>CC(=O)C[C@]1(O)C(=O)Nc2ccc([N+](=O)[O-])cc21</smiles>

$3 f(R)$-minor isomer
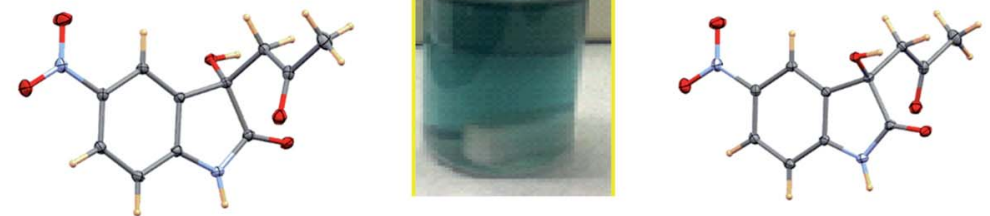

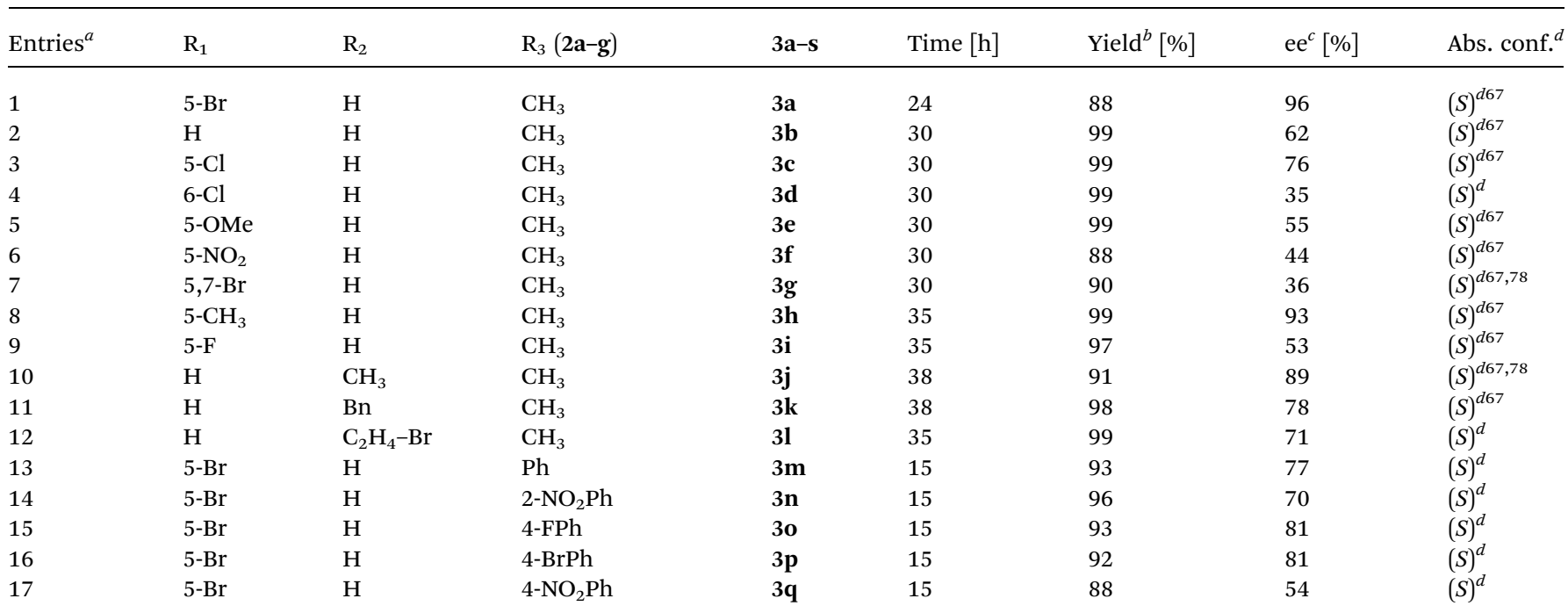



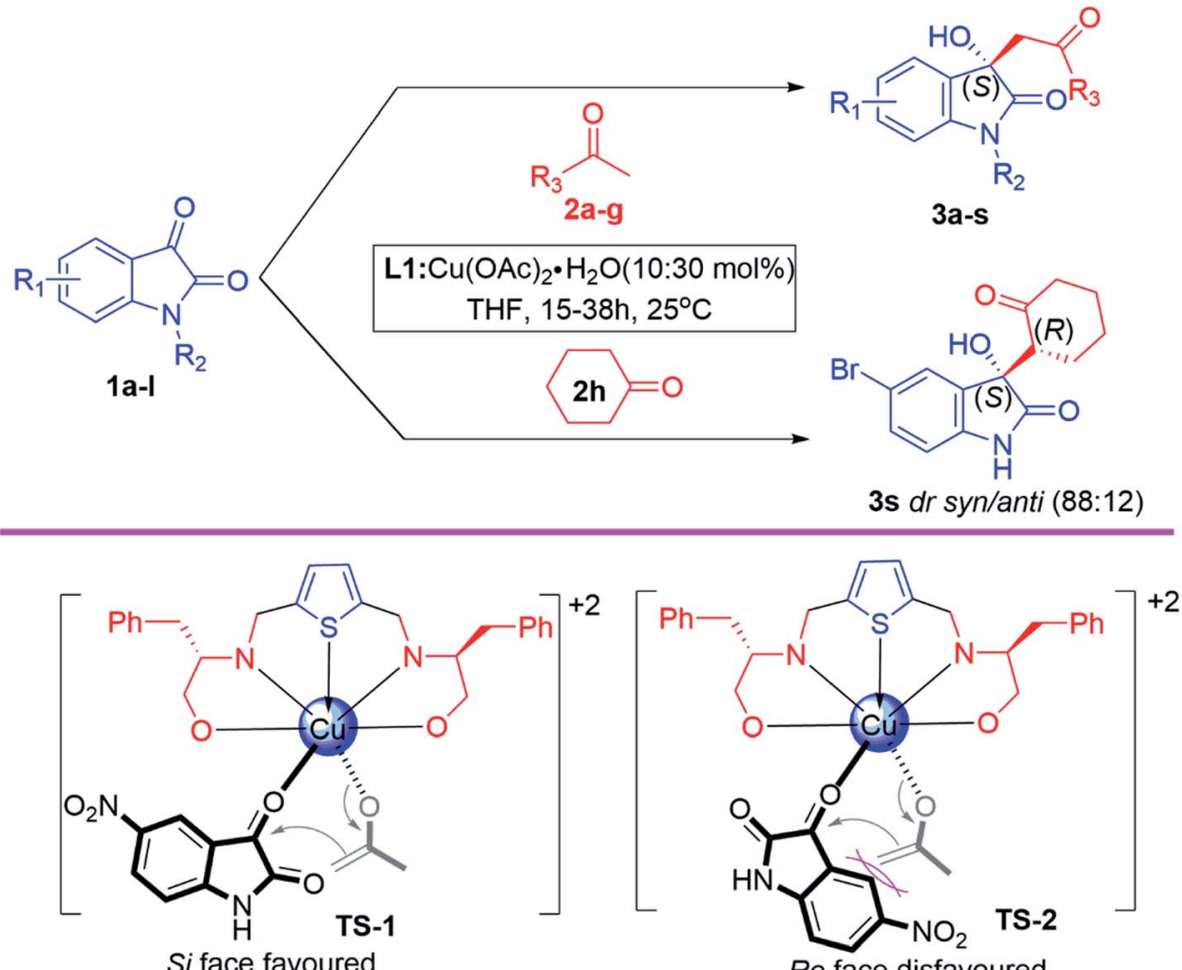<smiles>CC(=O)C[C@]1(O)C(=O)Nc2ccc([N+](=O)[O-])cc21</smiles>

Re face disfavoured 3f (S)-major isomer
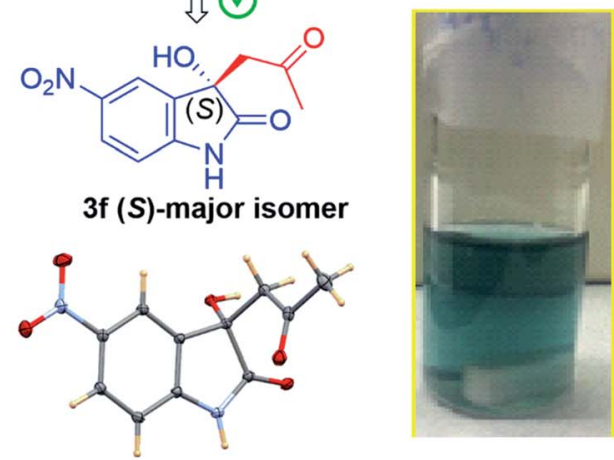<smiles>CC(=O)C[C@@]1(O)C(=O)Nc2ccc([N+](=O)[O-])cc21</smiles>

\section{$3 f(R)$-minor isomer}

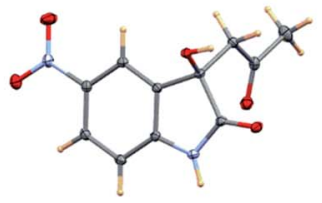

\begin{tabular}{|c|c|c|c|c|c|c|c|c|}
\hline Entries $^{a}$ & $\mathrm{R}_{1}$ & $\mathrm{R}_{2}$ & $\mathrm{R}_{3}(\mathbf{2 a}-\mathrm{g})$ & $3 a-s$ & Time $[\mathrm{h}]$ & Yield $^{b}[\%]$ & $\mathrm{ee}^{c}[\%]$ & Abs. conf. ${ }^{d}$ \\
\hline 18 & $5-\mathrm{Br}$ & $\mathrm{H}$ & 4-OHPh & $3 \mathbf{r}$ & 15 & 81 & 50 & $(S)^{d}$ \\
\hline 19 & $5-\mathrm{Br}$ & $\mathrm{H}$ & Cyclohexanone & $3 \mathrm{~s}$ & 35 & 99 & 85 & $(S, R)^{d 72}$ \\
\hline
\end{tabular}

${ }^{a}$ Reactions were performed on a $0.2 \mathrm{mmol}$ of isatin and $10.0 \mathrm{mmol}$ of acetone or cyclohexanone in 2 mL of THF. ${ }^{b}$ Isolated yields after column purification. ${ }^{c}$ Enantiomeric excess (ee) was determined by chiral HPLC using a Daicel Chiralpak AD-H/OD-H column $(25 \mathrm{~cm} \times 4.6 \mathrm{~mm} \times 5$ $\mu \mathrm{m}) .{ }^{d}$ Absolute configurations were determined by crystal structure and retention time matched with the literature.

expectation in inducing chirality in the aldol products and afforded 3d and $\mathbf{3 g}$ with poor enantioselectivities (35\% \& 36\% ee), however quantitative chemical yields were obtained (99\% \& 90\%) (Table 5, entries 4 \& 7).

In view of the above findings, we further investigated the efficiency of our best catalytic system L1-Cu(II) as a Lewis acid catalyst under the optimized reaction parameters. Subsequently, the asymmetric Aldol reaction of 5-bromo isatin (1a) with substituted acetone $(\mathbf{2} \mathbf{b}-\mathbf{e}, \mathbf{2 h})$ were carried out and the corresponding aldol product $\mathbf{3 m} \mathbf{m} \mathbf{p}$ and $3 \mathbf{s}$ were obtained in excellent yields (93\%, 96\%, 93\%, 92\% and 99\%) with very good enantiomeric excess (77\%, 70\%, 81\%, 81\% and 85\% ee) (Table 5 , entries $13-16,19)$. However, aldol product $\mathbf{3 q}$ and $3 \mathbf{r}$ were furnished in good yields (88\% and $81 \%)$ with moderate enantiomeric excess (54\% and 50\% ee) while using $p$-nitro and $p$ hydroxy acetophenone (2f, $\mathbf{2 g}$ ) as substrate for the Aldol reaction under optimized reaction conditions for $15 \mathrm{~h}$ and the findings are reported in Table 5, entries 13-19. 
Noteworthy to mention that, the $(S)$-enantiomer eluted faster than $(R)$-enantiomer in the HPLC chromatogram for aldol product $\mathbf{3 a}-\mathbf{c}, \mathbf{3 e - 1}$, while for the $N$-substituted aldol product $\mathbf{3 j}$, 3k and 31, reverse trends were followed, those are reported in the literature.$^{67,78}$ For aldol product $3 \mathrm{~s}$, retention time of synmajor/minor and anti-major/minor were well matched with the data available in the literature. ${ }^{72}$ Therefore, all the aldol products are predominantly found to be enriched with $(S)$ enantiomer as their retention time and optical rotations were absolutely in agreement with the literature data. ${ }^{67,78}$ The absolute configuration of compound $\mathbf{3 f}$ was further unambiguously confirmed by single-crystal X-ray analysis (CCDC number2143162, see ESI $\dagger$ S-64). In case of aldol products 3m-r the absolute configurations were also assigned as $(S)$-enantiomer, assuming that the reaction took place by following uniform mechanistic pathway (Fig. 3).

\section{Catalytic asymmetric studies of Domino Knoevenagel Michael cyclization}

To illustrate the generality for catalytic asymmetric application of our Lewis acid catalytic system (10 : $30 \mathrm{~mol} \%$ of L1-Cu(II) in THF at room temperature for 5-15 h), we extended the reaction scope and therefore catalytic asymmetric Domino Knoevenagel Michael cyclization reactions were performed using the same optimized parameters and the summary of the findings are documented in Table 6. From the results of Domino Knoevenagel Michael reaction, it can be clearly observed that the substituted isatins $(\mathbf{1 a}-\mathbf{l})$ reacted very well with malononitrile (4) and ethylacetoacetate (5) in order to furnished another set of biologically important oxindoles derivatives (6a-1) in excellent yields (89-99\%) and moderate to high enantiomeric excess (24$95 \%$ ee), those constitutes of spiro[4H-pyran-3,3'-oxindole] motif fused with 2-aminopyrans heterocyclic ring. It can be

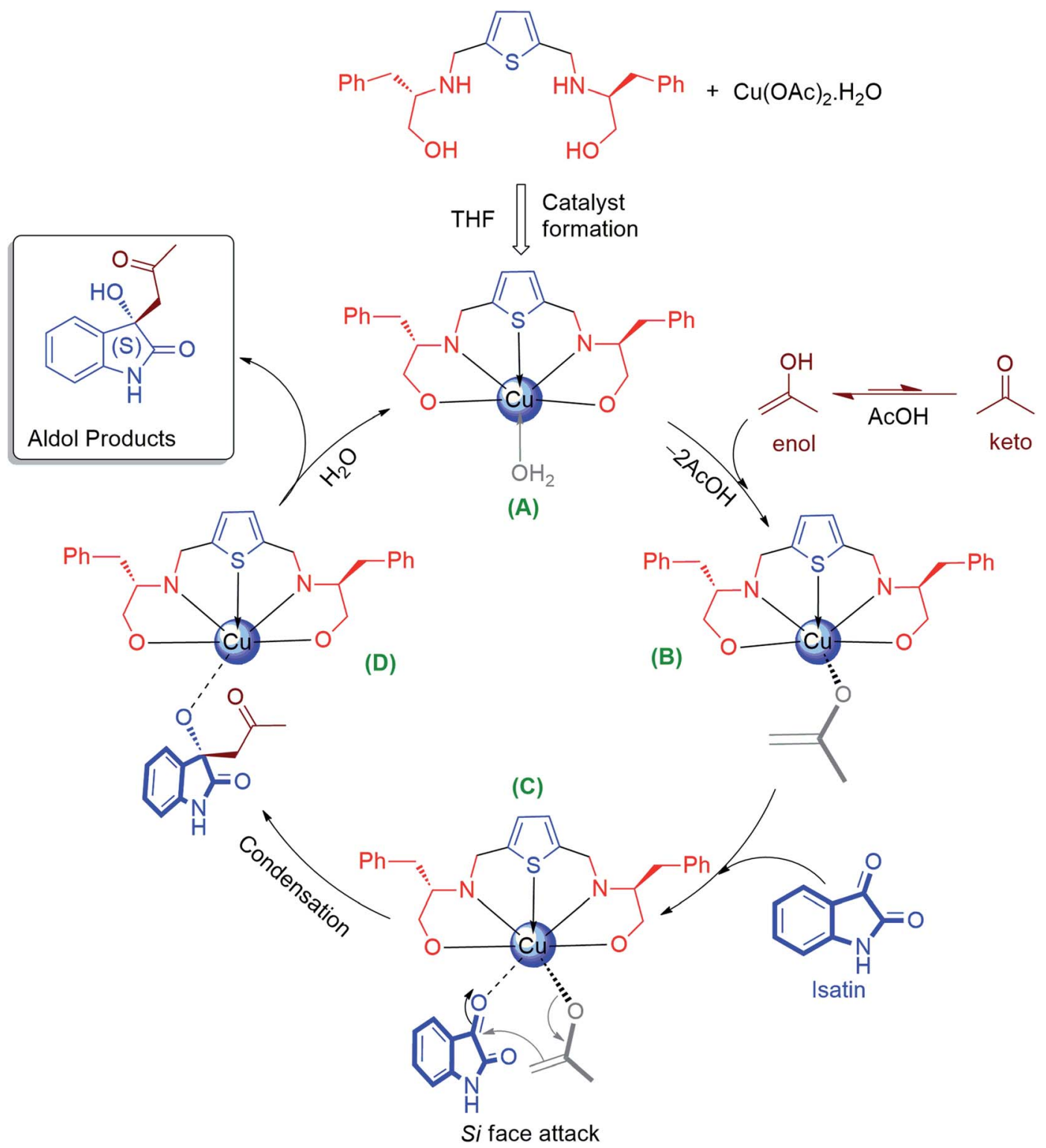

Fig. 3 Proposed mechanism of Lewis acid catalysis for asymmetric Aldol condensation reaction. 
Table $6 \mathrm{~L} 1-\mathrm{Cu}(\mathrm{OAc})_{2} \cdot \mathrm{H}_{2} \mathrm{O}$ catalyzed asymmetric three components one pot synthesis of spirooxindole using substituted isatin (1a-l), malononitrile (4) and ethylacetoacetate (5) under optimized reaction parameters

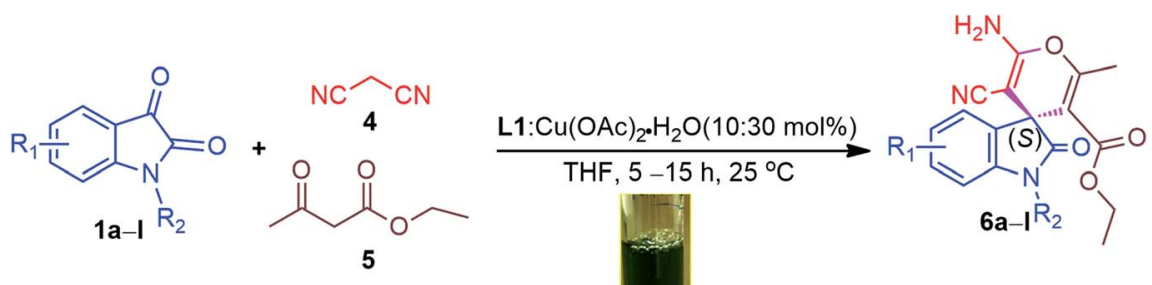

\begin{tabular}{|c|c|c|c|c|c|c|c|}
\hline Entry $^{a}$ & $\mathrm{R}_{1}$ & $\mathrm{R}_{2}$ & $6 a-1$ & Time $[\mathrm{h}]$ & Yield $^{b}[\%]$ & $\mathrm{ee}^{c}[\%]$ & Abs. conf \\
\hline 1 & $5-\mathrm{Br}$ & $\mathrm{H}$ & $6 a$ & 15 & 98 & 91 & $(S)^{97}$ \\
\hline 2 & $\mathrm{H}$ & $\mathrm{H}$ & $6 b$ & 13 & 99 & 42 & $(S)^{97}$ \\
\hline 3 & $5-\mathrm{Cl}$ & $\mathrm{H}$ & $6 c$ & 8 & 96 & 57 & $(S)^{97}$ \\
\hline 4 & 6-Cl & $\mathrm{H}$ & $6 d$ & 15 & 92 & 47 & $(S)$ \\
\hline 5 & $5-\mathrm{OCH}_{3}$ & $\mathrm{H}$ & $6 e$ & 15 & 93 & 87 & $(S)^{97}$ \\
\hline 6 & $5-\mathrm{NO}_{2}$ & $\mathrm{H}$ & $6 f$ & 15 & 89 & 80 & $(S)$ \\
\hline 7 & $5,7-\mathrm{Br}$ & $\mathrm{H}$ & $6 g$ & 15 & 96 & 50 & $(S)$ \\
\hline 8 & $5-\mathrm{CH}_{3}$ & $\mathrm{H}$ & $6 h$ & 15 & 97 & 95 & $(S)^{97}$ \\
\hline 9 & $5-\mathrm{F}$ & $\mathrm{H}$ & $6 \mathbf{i}$ & 15 & 98 & 39 & $(S)^{97}$ \\
\hline 10 & $\mathrm{H}$ & $\mathrm{CH}_{3}$ & $6 \mathbf{j}$ & 15 & 99 & 63 & $(S)^{97}$ \\
\hline 11 & $\mathrm{H}$ & $\mathrm{Bn}$ & $6 k$ & 15 & 98 & 81 & $(S)^{95,97}$ \\
\hline 12 & $\mathrm{H}$ & $\mathrm{C}_{2} \mathrm{H}_{4}-\mathrm{Br}$ & 61 & 5 & 89 & 24 & $(S)$ \\
\hline
\end{tabular}

${ }^{a}$ Reactions wer performed on a $0.2 \mathrm{mmol}$ of isatin in $2 \mathrm{~mL}$ of THF. ${ }^{b}$ Isolated yields after column purification. ${ }^{c}$ Enantiomeric excess (ee) was determined by chiral HPLC using a Daicel Chiralpak AD-H column $(25 \mathrm{~cm} \times 4.6 \mathrm{~mm} \times 5 \mu \mathrm{m}){ }^{d}$ Absolute configurations were determined by crystal structure and retention time matched with the literature.

noticed that this catalytic system produced best yields $(98 \%$, $93 \% \& 97 \%$ ) and enantiomeric excess (91\%, 87\% \& 95\% ee) when 5-bromo, 5-methoxy and 5-methyl isatins were subsequently used as substrate (Table 5, entries 1, 5 \& 8); while in case of 5-nitro and $N$-benzyl isatins, our catalytic system L1$\mathrm{Cu}(\mathrm{OAc})_{2} \cdot \mathrm{H}_{2} \mathrm{O}$ are also found to be quite capable of inducing pretty good chirality ( $80 \%$ \& $81 \%$ ee) with high yields ( $89 \%$ \& $98 \%$ ) accordingly (Table 6 , entries $6 \& 11$ ). In case of isatin and its derivatives such as 5-Cl, 6-Cl, 5,7-dibromo, 5-F and $\mathrm{N}$-Me isatins, the catalyst $\mathrm{L1}-\mathrm{Cu}(\mathrm{OAc})_{2} \cdot \mathrm{H}_{2} \mathrm{O}$ performed very well in terms of chemical yields (92-99\%) to produce corresponding spiro[4H-pyran-3,3'-oxindole] derivatives $\mathbf{6 b}-\mathbf{d}, \mathbf{6 g}, \mathbf{6 i}$ and $\mathbf{6 j}$ with moderate enantioselectivities $(41.7 \%, 57.1 \%, 47 \%, 50 \%$, $39 \%, 63 \%$ ee) (Table 6, entries 2-4, 7, 9 \& 10). Nevertheless, this catalytic system performed poorly in prompting chiral induction when $N$-ethylbromide isatin was used as substrate perhaps due to the steric hindrance caused by the two long chain of $N$ ethylbromide of substrate (11) and enol-ester (5) (Fig. 4) and the rate of reaction is comparatively high as it has taken 5 h only ( $89 \%$ yield, $24 \%$ ee). However chemical conversion is very good (Table 6, entry 12). All the Domino Knoevenagel Michael products are found to be enriched with (S)-enantiomer predominantly.

$(R)$-enantiomer eluted faster than $(S)$-enantiomer in the HPLC chromatogram for Domino Knoevenagel Michael cyclized spiro-oxindole products $\mathbf{6 a - c}, \mathbf{6 e}, \mathbf{6 h}$ and $\mathbf{6 i}$, while for the $N$ substituted spiro-oxindole $\mathbf{6 j}$, $\mathbf{6 k}$ and $\mathbf{6} \mathbf{l}$, reverse trends were followed, those are well reported in the literature. ${ }^{97}$ All the spirooxindole products are predominantly found to be enriched with $(S)$-enantiomer as their retention time and optical rotation were well in agreement with the literature data. ${ }^{97}$ The absolute configuration for spiro-oxindole products $\mathbf{6 d}, \mathbf{6 f}$ and $\mathbf{6 g}$ were also assigned as $(S)$-enantiomer as their retention time followed the similar trends as of compound $\mathbf{6 a - c}$, assuming that the reaction took place by following uniform mechanistic pathway (Fig. 4).

\section{Experimental}

\section{General}

All the chemicals (isatin, derivatives of isatin, acetone, acetone derivatives, metal salts) and solvents were purchased from Sigma-Aldrich and used as received. Thiophene-2,5-bis( $\beta$ amino-alcohol) ligands (L1-L5) were freshly synthesized from commercially available thiophene-2,5-dicarbaldehyde and chiral $\beta$-amino alcohols in a well dried flask under a static pressure of nitrogen. Standard procedures were followed for solvents drying before usage. Reactions were monitored by thin layer chromatography using Merck silica gel 60 Kieselgel F254 TLC (Merck, Kenilworth, NJ, USA) and column chromatography was performed on silica gel 100-200 (40-63 $\mu \mathrm{m}$, ASTM) from Merck using the proper solvents. ${ }^{1} \mathrm{H}$ and ${ }^{13} \mathrm{C}-\mathrm{NMR}$ spectra were recorded in $\mathrm{CDCl}_{3}$ and DMSO- $d_{6}$ on a Jeol Spectrometer (Jeol, Tokyo, Japan) (500 MHz). The chemical shifts are reported in ppm. All the racemic products were freshly prepared as per 


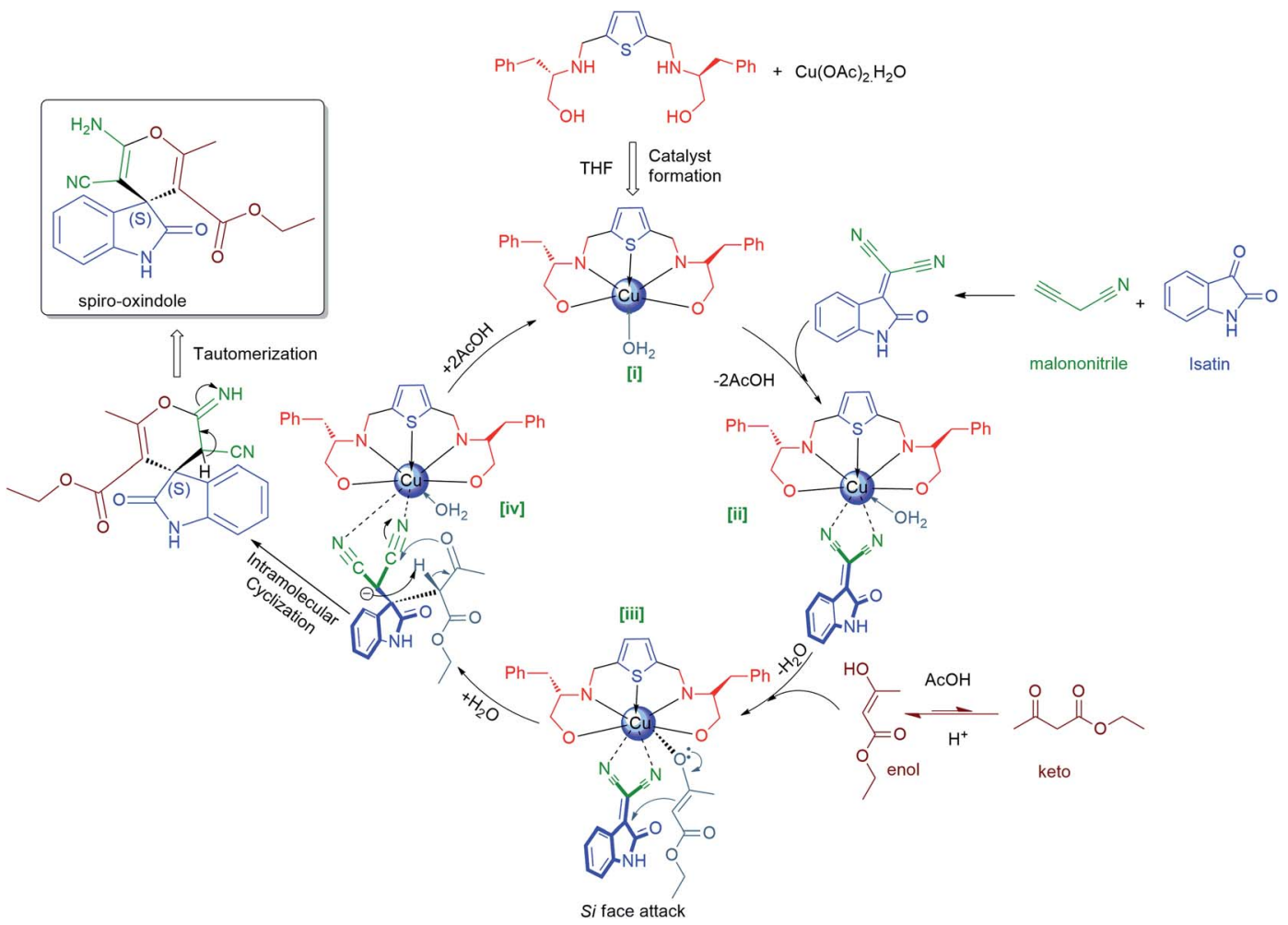

Fig. 4 Proposed mechanism of Lewis acid catalysis for asymmetric Domino Michael cyclization reaction.

the method reported in the literature..$^{83}$ Thermo Scientific Nicolet iS10 FT-IR spectrometer (Thermo Fisher Scientific, Waltham, MA, USA) has been used for Infrared spectra recording. Enantiomeric ratios were determined by analytical chiral HPLC analysis on a Shimadzu LC-20A (Shimadzu, Kyoto, Japan) Prominence instrument with a chiral stationary phase using Daicel OD-H columns (Chiral Technologies Europe, Illkirch-Graffenstaden, France) and 70-75\% $n$-hexane/ isopropanol as eluents (ESI $\dagger$ ). PerkinElmer-343 Polarimeter (PerkinElmer, Waltham, MA, USA) has been used for optical rotations measurement. Melting points (m.p.) were taken on a Thomas-Hoover capillary melting point apparatus (ThomasHoover, Texas City, USA) and were not corrected. Agilent Technologies 6410-triple quad LC/MS instrument (Agilent, Santa Clara, CA, USA) has been used for mass spectrometric analysis. PerkinElmer PE-2400 CHN Elemental Analyzer with autosampler has been used for elemental analysis only in CHN mode. X-ray diffraction data were collected on a Rigaku Oxford Diffraction Supernova diffractometer and processed with CrysAlisPro software v. 1.171.41.93a (Rigaku Oxford Diffraction, Yarnton, UK, 2020) using Cu K_ radiation”.

Synthesis of racemic aldol product rac.-(3a-s). A solution of isatin derivatives $(0.2 \mathrm{mmol})$, acetone $(10 \mathrm{mmol}) /$ derivative of acetone $(2.0 \mathrm{mmol})$ or cyclohexanone $(2.0 \mathrm{mmol})$ were taken into ethanol $(2 \mathrm{~mL})$ and two drops of diethylamine (DEA) were added to it, then the reaction was left stirring for $24 \mathrm{~h}$ at ambient temperature. The completion of the reaction was monitored by thin-layer chromatography (TLC) and the solvent was evaporated under reduced pressure to afford crude racemic aldol product which was purified by column chromatography on silica gel (100-200 mesh) using 40\% ethylacetate/ $n$-hexane as eluent to isolate the pure racemic aldol product rac.-(3a-s) (yield $75-88 \%)$.

Synthesis of racemic spiro-oxindole product rac.-(6a-1). A mixture of isatin derivatives $\mathbf{1 a}-\mathbf{1}(0.2 \mathrm{mmol})$, malononitrile 4 $(0.2 \mathrm{mmol})$ and ethylacetoacetate $5(0.2 \mathrm{mmol})$ were dissolved into ethanol $(2 \mathrm{~mL})$ at room temperature followed by addition of diethylamine (DEA) (two drops) and the reaction was stirred for 24-48 h. The completion of reaction was monitored by thinlayer chromatography (TLC). The solvent was removed under reduced pressure and the crude product was purified by column chromatography using silica gel (100-200 mesh) stationary phase and $60 \%$ ethylacetate $/ n$-hexane as eluent to afford the pure racemic spirooxindole product rac.-(6a-1) (yield 85-92\%).

\section{General procedure (GP1) for the catalytic asymmetric aldol} condensation reaction $(3 a-s)$

GP1. A small vial $(8 \mathrm{~mL})$ under nitrogen atmosphere were charged with ligand $\mathbf{L 1}$ (8.2 $\mathrm{mg}, 0.02 \mathrm{mmol}, 10 \mathrm{~mol} \%$ ), $\mathrm{Cu}(\mathrm{OAc})_{2} \cdot \mathrm{H}_{2} \mathrm{O}(12.0 \mathrm{mg}, 0.06 \mathrm{mmol}, 30 \mathrm{~mol} \%)$ and THF $(2 \mathrm{~mL})$. The solution was stirred for $2 \mathrm{~h}$ at room temperature and a blue coloured solution were observed, indicating formation of L1$\mathrm{Cu}(\mathrm{OAc})_{2} \cdot \mathrm{H}_{2} \mathrm{O}$ complex. The isatins $1 \mathrm{a}-\mathbf{l}(0.2 \mathrm{mmol})$ were then added to solution this solution and stirred for $10 \mathrm{~min}$ at room temperature followed by addition of acetone $2 \mathbf{a}(10 \mathrm{mmol})$ or substituted acetone $\mathbf{2 b}-\mathbf{g}(2.0 \mathrm{mmol})$ or cyclohexanone $\mathbf{2 h}(2.0$ $\mathrm{mmol}$ ) and the reaction mixture was left stirring for the 15-38 h. The solvents were then removed under reduced pressure and 
the residues were directly subjected to columns purification using 100 mesh silica gel and 40-70\% EtOAc/petroleum ether as eluents to obtain the corresponding chiral $\beta$-hydroxy ketones 3a-s as aldol product.

(S)-5-Bromo-3-hydroxy-3-(2-oxopropyl)indolin-2-one (3a). 5Bromoisatin 1a $(45.2 \mathrm{mg}, 0.2 \mathrm{mmol})$ and acetone $2 \mathrm{a}(581.0 \mathrm{mg}$, $10.0 \mathrm{mmol}$ ) were reacted according to the GP1 to afford product 3a as pale yellow solid; m.p.: $180-182^{\circ} \mathrm{C}$; isolated yield $(47.2 \mathrm{mg}$, $83 \%$ ). Enantiomeric excess (ee) was determined by chiral HPLC [Daicel Chiralpak AD-H column], 80.0\% $n$-hexane/i-PrOH, 1.0 $\mathrm{mL} \mathrm{min}^{-1}$; $t_{\text {major }}=9.64 \mathrm{~min} ; t_{\text {minor }}=13.91 \mathrm{~min} ; \lambda=254 \mathrm{~nm}$; $96 \%$ ee; $[\alpha]_{\mathrm{D}}^{20}=-9.57^{\circ}\left(c 0.05, \mathrm{CH}_{3} \mathrm{OH}\right) ;\left[\right.$ ref. $67[\alpha]_{\mathrm{D}}^{25}=-7.5^{\circ}(c$ $0.48, \mathrm{MeOH})] ;{ }^{1} \mathrm{H}-\mathrm{NMR}\left(500 \mathrm{MHz}, \mathrm{DMSO}-d_{6}\right): \delta(\mathrm{ppm})=10.35(\mathrm{~s}$, $1 \mathrm{H}, \mathrm{NH}), 7.43(\mathrm{~s}, 1 \mathrm{H}, \mathrm{Ar}-\mathrm{H}), 7.35$ (dd, $J=8.3,2.1 \mathrm{~Hz}, 1 \mathrm{H}, \mathrm{Ar}-\mathrm{H})$, $6.74(\mathrm{~d}, J=8.2 \mathrm{~Hz}, 1 \mathrm{H}, \mathrm{Ar}-\mathrm{H}), 6.09(\mathrm{~s}, 1 \mathrm{H}, \mathrm{OH}), 3.39$ (d, $J=$ $\left.17.3 \mathrm{~Hz}, 1 \mathrm{H}, \mathrm{CH}_{2(\mathrm{a})}\right), 3.06\left(\mathrm{~d}, J=17.3 \mathrm{~Hz}, 1 \mathrm{H}, \mathrm{CH}_{2(\mathrm{~b})}\right), 2.01(\mathrm{~s}, 1 \mathrm{H}$, $\left.\mathrm{CH}_{3}\right) ;{ }^{13} \mathrm{C}-\mathrm{NMR}\left(126 \mathrm{MHz}\right.$, DMSO- $\left.d_{6}\right): \delta(\mathrm{ppm})=205.33,177.76$, $142.02,134.17,131.53,126.67,112.92,111.38,72.58,49.96$, 30.31. All the analytical data are well in agreement with the reported literature. ${ }^{67}$

(S)-3-Hydroxy-3-(2-oxopropyl)indolin-2-one (3b). Isatin $\mathbf{1 b}$ $(29.4 \mathrm{mg}, 0.2 \mathrm{mmol})$ and acetone $2 \mathrm{a}(581.0 \mathrm{mg}, 10.0 \mathrm{mmol})$ were reacted according to the GP1 to yield product $\mathbf{3 b}$ as pale yellow solid; m.p.: $169-171{ }^{\circ} \mathrm{C}$; isolated yield (40.6 mg, 99\%). Enantiomeric excess (ee) was determined by chiral HPLC [Daicel Chiralpak AD-H column], $80.0 \% \quad n$-hexane/i-PrOH, 1.0 $\mathrm{mL} \min ^{-1} ; t_{\text {major }}=9.88 \mathrm{~min} ; t_{\text {minor }}=13.29 \min ; \lambda=254 \mathrm{~nm}$; $62 \%$ ee; $[\alpha]_{\mathrm{D}}^{20}=-12.65^{\circ}\left(c 0.04, \mathrm{CH}_{3} \mathrm{OH}\right) ;\left[\right.$ ref. $67[\alpha]_{\mathrm{D}}^{25}=-31.6^{\circ}$ $(c 1.37, \mathrm{MeOH})] ;{ }^{1} \mathrm{H}-\mathrm{NMR}\left(500 \mathrm{MHz}, \mathrm{DMSO}-d_{6}\right): \delta(\mathrm{ppm})=10.21$ (s, $1 \mathrm{H}, \mathrm{NH}), 7.24(\mathrm{~d}, J=7.4 \mathrm{~Hz}, 1 \mathrm{H}, \mathrm{Ar}-\mathrm{H}), 7.17$ (td, $J=7.6$, $1.3 \mathrm{~Hz}, 1 \mathrm{H}, \mathrm{Ar}-\mathrm{H}), 6.90(\mathrm{td}, J=7.5,1.0 \mathrm{~Hz}, 1 \mathrm{H}, \mathrm{Ar}-\mathrm{H}), 6.78(\mathrm{~d}, J=$ $7.6 \mathrm{~Hz}, 1 \mathrm{H}, \mathrm{Ar}-\mathrm{H}), 5.97$ (s, 1H, OH), 3.27 (d, $J=16.5 \mathrm{~Hz}, 1 \mathrm{H}$, $\left.\mathrm{CH}_{2(\mathrm{a})}\right), 3.00\left(\mathrm{~d}, J=16.5 \mathrm{~Hz}, 1 \mathrm{H}, \mathrm{CH}_{2(\mathrm{~b})}\right), 2.00\left(\mathrm{~s}, 1 \mathrm{H}, \mathrm{CH}_{3}\right) ;{ }^{13} \mathrm{C}-$ NMR $\left(126 \mathrm{MHz}\right.$, DMSO- $\left.d_{6}\right): \delta(\mathrm{ppm})=205.18,178.17,142.55$, 131.53, 128.99, 123.70, 121.24, 109.43, 72.66, 50.28, 30.58. All the analytical data are well in agreement with the reported literature. ${ }^{67}$

(S)-5-Chloro-3-hydroxy-3-(2-oxopropyl)indolin-2-one (3c). 5Chloroisatin 1c $(47.9 \mathrm{mg}, 0.2 \mathrm{mmol})$ and acetone $2 \mathrm{a}(581.0 \mathrm{mg}$, $10.0 \mathrm{mmol}$ ) were reacted according to the GP1 to yield product $3 \mathbf{c}$ as pale yellow solid; m.p.: $155-157^{\circ} \mathrm{C}$; isolated yield $(47.5 \mathrm{mg}$, 99\%). Enantiomeric excess (ee) was determined by chiral HPLC [Daicel Chiralpak AD-H column], 80.0\% $n$-hexane/i-PrOH, 1.0

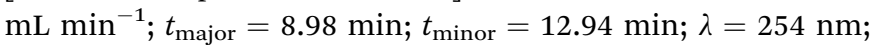
$76 \%$ ee; $[\alpha]_{\mathrm{D}}^{20}=-5.57^{\circ}\left(c 0.04, \mathrm{CH}_{3} \mathrm{OH}\right) ;\left[\right.$ ref. $67[\alpha]_{\mathrm{D}}^{25}=-9.3^{\circ}(c$ $0.9, \mathrm{MeOH})] ;{ }^{1} \mathrm{H}-\mathrm{NMR}\left(500 \mathrm{MHz}, \mathrm{DMSO}-d_{6}\right): \delta(\mathrm{ppm})=10.34(\mathrm{~s}$, $1 \mathrm{H}, \mathrm{NH}), 7.31$ (d, $J=2.2 \mathrm{~Hz}, 1 \mathrm{H}, \mathrm{Ar}-\mathrm{H}), 7.23-7.20(\mathrm{~m}, 1 \mathrm{H}, \mathrm{Ar}-\mathrm{H})$, $6.87(\mathrm{~d}, J=8.2 \mathrm{~Hz}, 1 \mathrm{H}, \mathrm{Ar}-\mathrm{H}), 6.09(\mathrm{~s}, 1 \mathrm{H}, \mathrm{OH}), 3.38$ (d, $J=$ $\left.17.3 \mathrm{~Hz}, 1 \mathrm{H}, \mathrm{CH}_{2(\mathrm{a})}\right), 3.06\left(\mathrm{~d}, J=17.3 \mathrm{~Hz}, 1 \mathrm{H}, \mathrm{CH}_{2(\mathrm{~b})}\right), 2.01(\mathrm{~s}, 1 \mathrm{H}$, $\left.\mathrm{CH}_{3}\right) ;{ }^{13} \mathrm{C}-\mathrm{NMR}\left(126 \mathrm{MHz}\right.$, DMSO- $\left.d_{6}\right): \delta(\mathrm{ppm})=205.31,177.90$, 141.60, 133.76, 128.68, 125.21, 123.98, 110.81, 72.62, 49.96, 30.32. All the analytical data are well in agreement with the reported literature ${ }^{67}$

(S)-6-Chloro-3-hydroxy-3-(2-oxopropyl)indolin-2-one (3d). 6Chloroisatin 1d (47.9 mg, $0.2 \mathrm{mmol})$ and acetone $2 \mathrm{a}(581.0 \mathrm{mg}$, $10.0 \mathrm{mmol}$ ) were reacted according to the GP1 to yield product 3d as pale yellow solid; m.p.: $170-172{ }^{\circ} \mathrm{C}$; isolated yield
(47.5 mg, 99\%). Enantiomeric excess (ee) was determined by chiral HPLC [Daicel Chiralpak AD-H column], 80.0\% $n$-hexane/i-

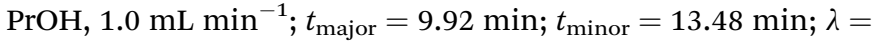
$254 \mathrm{~nm} ; 35 \%$ ee; $[\alpha]_{\mathrm{D}}^{20}=-9.99^{\circ}\left(c 0.05, \mathrm{CH}_{3} \mathrm{OH}\right) ; \mathrm{IR}(\mathrm{KBr}): 3364$, 3242, 2924, 2853, 1712, 1620, 1484, 1448, 1362, 1339, 1227, $1185,1072,825,780,732,654,587,565,551 \mathrm{~cm}^{-1} ;{ }^{1} \mathrm{H}-\mathrm{NMR}(500$ MHz, DMSO- $\left.d_{6}\right): \delta(\mathrm{ppm})=10.38(\mathrm{~s}, 1 \mathrm{H}, \mathrm{NH}), 7.25(\mathrm{~d}, J=7.9 \mathrm{~Hz}$, $1 \mathrm{H}, \mathrm{Ar}-\mathrm{H}), 6.95$ (dd, $J=7.9,2.0 \mathrm{~Hz}, 1 \mathrm{H}, \mathrm{Ar}-\mathrm{H}), 6.79(\mathrm{~d}, J=$ $1.9 \mathrm{~Hz}, 1 \mathrm{H}, \mathrm{Ar}-\mathrm{H}), 6.06$ (s, 1H, OH), 3.34 (d, $J=16.8 \mathrm{~Hz}, 1 \mathrm{H}$, $\left.\mathrm{CH}_{2(\mathrm{a})}\right), 3.06\left(\mathrm{~d}, J=17.1 \mathrm{~Hz}, 1 \mathrm{H}, \mathrm{CH}_{2(\mathrm{~b})}\right), 2.00\left(\mathrm{~s}, 1 \mathrm{H}, \mathrm{CH}_{3}\right) ;{ }^{13} \mathrm{C}-$ NMR $\left(126 \mathrm{MHz}\right.$, DMSO- $\left.d_{6}\right): \delta(\mathrm{ppm})=205.30,178.15,144.26$, 133.18, 130.57, 125.16, 120.89, 109.48, 72.17, 50.06, 30.39; LC/ MS (ESI): found $240.1\left[\mathrm{M}\left({ }^{35} \mathrm{Cl}\right)+\mathrm{H}\right]^{+} ; 242.0\left[\mathrm{M}\left({ }^{37} \mathrm{Cl}\right)+\mathrm{H}\right]^{+}$, $\mathrm{C}_{11} \mathrm{H}_{10} \mathrm{ClNO}_{3}$ requires 239.03; anal. calcd for $\mathrm{C}_{11} \mathrm{H}_{10} \mathrm{ClNO}_{3}$ : C, $55.13 ; \mathrm{H}, 4.21$; N, 5.84; found: C, 54.96; H, 4.15; N, 6.06.

(S)-3-Hydroxy-5-methoxy-3-(2-oxopropyl)indolin-2-one (3e). 5Methoxyisatin 1e (35.4 mg, $0.2 \mathrm{mmol})$ and acetone $2 \mathrm{a}(581.0 \mathrm{mg}$, $10.0 \mathrm{mmol}$ ) were reacted according to the GP1 to yield product 3e as pale yellow solid; m.p.: $165-167^{\circ} \mathrm{C}$; isolated yield $(46.6 \mathrm{mg}$, 99\%). Enantiomeric excess (ee) was determined by chiral HPLC [Daicel Chiralpak AD-H column], 80.0\% $n$-hexane/i-PrOH, 1.0

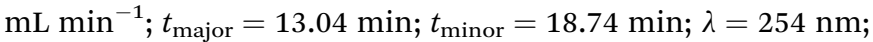
$55 \%$ ee; $[\alpha]_{\mathrm{D}}^{20}=-3.45^{\circ}\left(c 0.06, \mathrm{CH}_{3} \mathrm{OH}\right) ;\left[\right.$ ref. $67[\alpha]_{\mathrm{D}}^{25}=-3.9^{\circ}(c$ $1.17, \mathrm{MeOH})] ;{ }^{1} \mathrm{H}-\mathrm{NMR}\left(500 \mathrm{MHz}, \mathrm{DMSO}-d_{6}\right): \delta(\mathrm{ppm})=10.04(\mathrm{~s}$, $1 \mathrm{H}, \mathrm{NH}), 6.91(\mathrm{~d}, J=2.6 \mathrm{~Hz}, 1 \mathrm{H}, \mathrm{Ar}-\mathrm{H}), 6.74(\mathrm{dd}, J=8.4,2.6 \mathrm{~Hz}$, $1 \mathrm{H}, \mathrm{Ar}-\mathrm{H}), 6.69$ (d, $J=8.4 \mathrm{~Hz}, 1 \mathrm{H}, \mathrm{Ar}-\mathrm{H}), 5.97(\mathrm{~s}, 1 \mathrm{H}, \mathrm{OH}), 3.69$ (s, $\left.3 \mathrm{H}, \mathrm{OCH}_{3}\right), 3.27$ (d, $\left.J=16.6 \mathrm{~Hz}, 1 \mathrm{H}, \mathrm{CH}_{2(\mathrm{a})}\right), 3.00$ (d, $J=$ $\left.16.6 \mathrm{~Hz}, 1 \mathrm{H}, \mathrm{CH}_{2(\mathrm{~b})}\right), 2.01\left(\mathrm{~s}, 1 \mathrm{H}, \mathrm{CH}_{3}\right) ;{ }^{13} \mathrm{C}-\mathrm{NMR}(126 \mathrm{MHz}$, DMSO- $\left.d_{6}\right): \delta(\mathrm{ppm})=205.17,178.11,154.68,135.74,132.81$, $113.36,111.01,109.72,73.09,55.44,50.26,30.59$. All the analytical data are well in agreement with the reported literature. ${ }^{67}$

(S)-3-Hydroxy-5-nitro-3-(2-oxopropyl)indolin-2-one (3f). 5Nitroisatin 1f $(38.4 \mathrm{mg}, 0.2 \mathrm{mmol})$ and acetone $2 \mathrm{a}(581.0 \mathrm{mg}$, $10.0 \mathrm{mmol}$ ) were reacted according to the GP1 to yield product 3f as pale yellow solid; m.p.: $178-180^{\circ} \mathrm{C}$; isolated yield $(44.1 \mathrm{mg}$, $88 \%$ ). Enantiomeric excess (ee) was determined by chiral HPLC [Daicel Chiralpak AD-H column], 80.0\% $n$-hexane/i-PrOH, 1.0 $\mathrm{mL} \mathrm{min}^{-1} ; t_{\text {major }}=12.11 \mathrm{~min} ; t_{\text {minor }}=15.78 \mathrm{~min} ; \lambda=254 \mathrm{~nm}$; $44 \%$ ee; $[\alpha]_{\mathrm{D}}^{20}=-2.32^{\circ}\left(c 0.04, \mathrm{CH}_{3} \mathrm{OH}\right) ;\left[\right.$ ref. $67[\alpha]_{\mathrm{D}}^{25}=-21.7^{\circ}(c$ $1.10, \mathrm{MeOH})] ;{ }^{1} \mathrm{H}-\mathrm{NMR}\left(500 \mathrm{MHz}, \mathrm{DMSO}-d_{6}\right): \delta(\mathrm{ppm})=10.96(\mathrm{~s}$, $1 \mathrm{H}, \mathrm{NH}), 8.18-8.16(\mathrm{~m}, 2 \mathrm{H}, \mathrm{Ar}-\mathrm{H}), 6.99(\mathrm{~d}, J=9.2 \mathrm{~Hz}, 1 \mathrm{H}, \mathrm{Ar}-\mathrm{H})$, $6.28(\mathrm{~s}, 1 \mathrm{H}, \mathrm{OH}), 3.61\left(\mathrm{~d}, J=17.8 \mathrm{~Hz}, 1 \mathrm{H}, \mathrm{CH}_{2(\mathrm{a})}\right), 3.18(\mathrm{~d}, J=$ $\left.17.9 \mathrm{~Hz}, 1 \mathrm{H}, \mathrm{CH}_{2(\mathrm{~b})}\right), 2.02\left(\mathrm{~s}, 1 \mathrm{H}, \mathrm{CH}_{3}\right) ;{ }^{13} \mathrm{C}-\mathrm{NMR}(126 \mathrm{MHz}$, DMSO- $\left.d_{6}\right): \delta(\mathrm{ppm})=205.62,178.59,149.49,141.93,132.79$, $126.42,119.50,109.54,72.09,49.88$, 30.04. All the analytical data are well in agreement with the reported literature. ${ }^{67}$

(S)-5,7-Dibromo-3-hydroxy-3-(2-oxopropyl)indolin-2-one (3g). 5,7-Dibromoisatin $1 \mathrm{~g}(61.0 \mathrm{mg}, 0.2 \mathrm{mmol})$ and acetone $2 \mathrm{a}$ $(581.0 \mathrm{mg}, 10.0 \mathrm{mmol}$ ) were reacted according to the GP1 to yield product $3 \mathrm{~g}$ as pale yellow solid; m.p.: $182-184{ }^{\circ} \mathrm{C}$; isolated yield $(65.3 \mathrm{mg}, 90 \%)$. Enantiomeric excess (ee) was determined by chiral HPLC [Daicel Chiralpak AD-H column], $80.0 \% n$ -

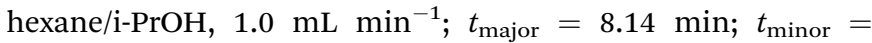
$10.02 \mathrm{~min} ; \lambda=254 \mathrm{~nm} ; 36 \%$ ee; $[\alpha]_{\mathrm{D}}^{20}=-4.41^{\circ}\left(c 0.05, \mathrm{CH}_{3} \mathrm{OH}\right)$; [ref. $67[\alpha]_{\mathrm{D}}^{25}=-9.4^{\circ}\left(c\right.$ 2.14, MeOH)]; ${ }^{1} \mathrm{H}-\mathrm{NMR}(500 \mathrm{MHz}$, DMSO- $\left.d_{6}\right): \delta(\mathrm{ppm})=10.70(\mathrm{~s}, 1 \mathrm{H}, \mathrm{NH}), 7.61(\mathrm{~d}, J=1.9 \mathrm{~Hz}, 1 \mathrm{H}$, 
$\mathrm{Ar}-\mathrm{H}), 7.47$ (d, J=1.9 Hz, 1H, Ar-H), 6.24 (s, 1H, OH), 3.46 (d, $\left.=17.7 \mathrm{~Hz}, 1 \mathrm{H}, \mathrm{CH}_{2(\mathrm{a})}\right), 3.14\left(\mathrm{~d}, J=17.7 \mathrm{~Hz}, 1 \mathrm{H}, \mathrm{CH}_{2(\mathrm{~b})}\right), 2.02(\mathrm{~s}$, $\left.1 \mathrm{H}, \mathrm{CH}_{3}\right) ;{ }^{13} \mathrm{C}-\mathrm{NMR}\left(126 \mathrm{MHz}, \mathrm{DMSO}-d_{6}\right): \delta(\mathrm{ppm})=205.48$, 177.65, 141.79, 135.48, 133.40, 125.81, 113.41, 102.53, 73.34, $49.99,30.10$. All the analytical data are well in agreement with the reported literature. ${ }^{67}$

(S)-3-Hydroxy-5-methyl-3-(2-oxopropyl)indolin-2-one (3h). 5Methylisatin $\mathbf{1 h}(32.2 \mathrm{mg}, 0.2 \mathrm{mmol})$ and acetone $2 \mathrm{a}(581.0 \mathrm{mg}$, $10.0 \mathrm{mmol}$ ) were reacted according to the GP1 to yield product 3h as white solid; m.p.: $165-167{ }^{\circ} \mathrm{C}$; isolated yield $(43.9 \mathrm{mg}$, 99\%). Enantiomeric excess (ee) was determined by chiral HPLC [Daicel Chiralpak AD-H column], 90.0\% $n$-hexane/i-PrOH, 1.0

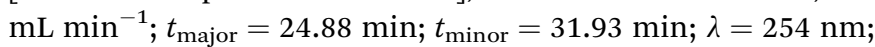
$93 \%$ ee; $[\alpha]_{\mathrm{D}}^{20}=-5.10^{\circ}\left(c 0.05, \mathrm{CH}_{3} \mathrm{OH}\right) ;\left[\right.$ ref. $67[\alpha]_{\mathrm{D}}^{25}=-2.8^{\circ}(c$ $0.81, \mathrm{MeOH})] ;{ }^{1} \mathrm{H}-\mathrm{NMR}\left(500 \mathrm{MHz}, \mathrm{DMSO}-d_{6}\right): \delta(\mathrm{ppm})=10.12(\mathrm{~s}$, $1 \mathrm{H}, \mathrm{NH}), 7.07$ (s, 1H, Ar-H), 6.99-6.95 (m, 1H, Ar-H), 6.67 (d, J= $7.8 \mathrm{~Hz}, 1 \mathrm{H}, \mathrm{Ar}-\mathrm{H}), 5.94(\mathrm{~s}, 1 \mathrm{H}, \mathrm{OH}), 3.24(\mathrm{~d}, J=16.6 \mathrm{~Hz}, 1 \mathrm{H}$, $\mathrm{CH}_{2(\mathrm{a})}$ ), 3.00 (d, $\left.J=16.6 \mathrm{~Hz}, 1 \mathrm{H}, \mathrm{CH}_{2(\mathrm{~b})}\right), 2.23\left(\mathrm{~s}, 1 \mathrm{H}, \mathrm{CH}_{3}\right), 2.01$ $\left(\mathrm{s}, 3 \mathrm{H}, \mathrm{CH}_{3}\right) ;{ }^{13} \mathrm{C}-\mathrm{NMR}\left(126 \mathrm{MHz}, \mathrm{DMSO}-d_{6}\right): \delta(\mathrm{ppm})=205.21$, 178.23, 140.10, 131.65, 130.03, 129.17, 124.41, 109.21, 72.80, $50.36,30.60,20.73$. All the analytical data are well in agreement with the reported literature. ${ }^{67}$

(S)-5-Fluoro-3-hydroxy-3-(2-oxopropyl)indolin-2-one (3i). 5-Fluoroisatin $1 \mathrm{i}(33.0 \mathrm{mg}, 0.2 \mathrm{mmol})$ and acetone $2 \mathrm{a}(581.0 \mathrm{mg}, 10.0$ $\mathrm{mmol}$ ) were reacted according to the GP1 to yield product $\mathbf{3 i}$ as pale yellow solid; $184-186{ }^{\circ} \mathrm{C}$; isolated yield (43.3 $\mathrm{mg}, 97 \%$ ). Enantiomeric excess (ee) was determined by chiral HPLC [Daicel Chiralpak AD-H column], 80.0\% $n$-hexane/i-PrOH, 1.0 $\mathrm{mL} \min ^{-1} ; t_{\text {major }}=9.21 \mathrm{~min} ; t_{\text {minor }}=12.36 \mathrm{~min} ; \lambda=254 \mathrm{~nm}$; $53 \%$ ee; $[\alpha]_{\mathrm{D}}^{20}=-11.49^{\circ}\left(c 0.06, \mathrm{CH}_{3} \mathrm{OH}\right) ;[\alpha]_{\mathrm{D}}^{25}=-19.0^{\circ}(c 0.97$, $\mathrm{MeOH}) ;{ }^{67}{ }^{1} \mathrm{H}-\mathrm{NMR}\left(500 \mathrm{MHz}, \mathrm{DMSO}-d_{6}\right): \delta(\mathrm{ppm})=10.25(\mathrm{~s}, 1 \mathrm{H}$, $\mathrm{NH}), 7.15(\mathrm{dd}, J=8.2,2.7 \mathrm{~Hz}, 1 \mathrm{H}, \mathrm{Ar}-\mathrm{H}), 7.02-7.98(\mathrm{~m}, 1 \mathrm{H}, \mathrm{Ar}-$ $\mathrm{H}), 6.76(\mathrm{dd}, J=8.5,4.3 \mathrm{~Hz}, 1 \mathrm{H}, \mathrm{Ar}-\mathrm{H}), 6.10(\mathrm{~s}, 1 \mathrm{H}, \mathrm{OH}), 3.34$ (d, $\left.J=17.0 \mathrm{~Hz}, 1 \mathrm{H}, \mathrm{CH}_{2(\mathrm{a})}\right), 3.06\left(\mathrm{~d}, J=17.0 \mathrm{~Hz}, 1 \mathrm{H}, \mathrm{CH}_{2(\mathrm{~b})}\right), 2.01$ (s, $\left.3 \mathrm{H}, \mathrm{CH}_{3}\right) ;{ }^{13} \mathrm{C}-\mathrm{NMR}\left(126 \mathrm{MHz}, \mathrm{DMSO}-d_{6}\right): \delta(\mathrm{ppm})=205.28$, $178.23,158.83 \& 156.95\left(\mathrm{C}_{1}-\mathrm{F}, J_{\mathrm{C}-\mathrm{F}}=236.75 \mathrm{~Hz}\right), 138.82,133.45$ $\& 133.39\left(\mathrm{C}_{2}-\mathrm{F}, J_{\mathrm{C}-\mathrm{F}}=7.56 \mathrm{~Hz}\right), 115.14 \& 114.96\left(\mathrm{C}_{3}-\mathrm{F}, J_{\mathrm{C}-\mathrm{F}}=\right.$ $23.44 \mathrm{~Hz}), 111.78 \& 111.58\left(\mathrm{C}_{5}-\mathrm{F}, J_{\mathrm{C}-\mathrm{F}}=24.44 \mathrm{~Hz}\right), 110.15$ \& $110.09\left(\mathrm{C}_{6}-\mathrm{F}, J_{\mathrm{C}-\mathrm{F}}=7.81 \mathrm{~Hz}\right), 72.92,50.06,30.44$. All the analytical data are well in agreement with the reported literature. ${ }^{67}$

(S)-3-Hydroxy-1-methyl-3-(2-oxopropyl)indolin-2-one (3j). 1Methylisatin $1 \mathbf{j}(32.2 \mathrm{mg}, 0.2 \mathrm{mmol})$ and acetone $2 \mathrm{a}(581.0 \mathrm{mg}$, $10.0 \mathrm{mmol}$ ) were reacted according to the GP1 to yield product 3 j as pale yellow solid; m.p.: $154-156{ }^{\circ} \mathrm{C}$; isolated yield $(43.0 \mathrm{mg}$, 98\%). Enantiomeric excess (ee) was determined by chiral HPLC [Chiralcel OD-H column], 90.0\% $n$-hexane/i-PrOH, 1.0 $\mathrm{mL} \mathrm{min}^{-1} ; t_{\text {minor }}=19.93 \mathrm{~min} ; t_{\text {major }}=21.09 \mathrm{~min} ; \lambda=254 \mathrm{~nm}$; $87 \%$ ee; $[\alpha]_{\mathrm{D}}^{20}=-21.94^{\circ}\left(c 0.05, \mathrm{CH}_{3} \mathrm{OH}\right) ;\left[\right.$ ref. $67[\alpha]_{\mathrm{D}}^{25}=-22.3^{\circ}$ $(c 1.59, \mathrm{MeOH})] ;{ }^{1} \mathrm{H}-\mathrm{NMR}\left(500 \mathrm{MHz}, \mathrm{DMSO}-d_{6}\right): \delta(\mathrm{ppm})=7.31-$ 7.25 (m, 2H, Ar-H), 6.99 (td, $J=7.5,1.0 \mathrm{~Hz}, 1 \mathrm{H}, \mathrm{Ar}-\mathrm{H}), 6.96(\mathrm{~d}, J$ $=7.7 \mathrm{~Hz}, 1 \mathrm{H}, \mathrm{Ar}-\mathrm{H}), 6.06(\mathrm{~s}, 1 \mathrm{H}, \mathrm{OH}), 3.34(\mathrm{~d}, J=16.8 \mathrm{~Hz}, 1 \mathrm{H}$, $\left.\mathrm{CH}_{2(\mathrm{a})}\right), 3.09$ (s, 3H, $\mathrm{NCH}_{3}$ ), 3.05 (d, $\left.J=16.8 \mathrm{~Hz}, 1 \mathrm{H}, \mathrm{CH}_{2(\mathrm{~b})}\right), 1.98$ $\left(\mathrm{s}, 1 \mathrm{H}, \mathrm{CH}_{3}\right) ;{ }^{13} \mathrm{C}-\mathrm{NMR}\left(126 \mathrm{MHz}, \mathrm{DMSO}-d_{6}\right): \delta(\mathrm{ppm})=205.13$, 176.50, 144.05, 130.90, 129.14, 123.25, 121.94, 108.26, 72.33, $50.42,30.47,25.89$. All the analytical data are well in agreement with the reported literature. ${ }^{67}$
(S)-1-Benzyl-3-hydroxy-3-(2-oxopropyl)indolin-2-one (3k). 1Benzylisatin 1k $(47.5 \mathrm{mg}, 0.2 \mathrm{mmol})$ and acetone $2 \mathrm{a}(581.0 \mathrm{mg}$, $10.0 \mathrm{mmol}$ ) were reacted according to the GP1 to yield product 3k as pale yellow solid; m.p.: $170-173{ }^{\circ} \mathrm{C}$; isolated yield $(57.9 \mathrm{mg}$, 98\%). Enantiomeric excess (ee) was determined by chiral HPLC [Daicel Chiralpak AD-H column], 85.0\% $n$-hexane/i-PrOH, 1.0

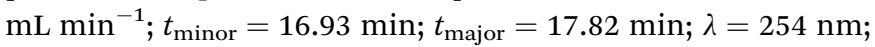
$78 \%$ ee; $[\alpha]_{\mathrm{D}}^{20}=-16.23^{\circ}\left(c 0.06, \mathrm{CH}_{3} \mathrm{OH}\right) ;\left[\right.$ ref. $67[\alpha]_{\mathrm{D}}^{25}=-17.8^{\circ}$ $(c 1.53, \mathrm{MeOH})] ;{ }^{1} \mathrm{H}-\mathrm{NMR}\left(500 \mathrm{MHz}, \mathrm{DMSO}-d_{6}\right): \delta(\mathrm{ppm})=7.48-$ $7.43\left(\mathrm{~m}, 2 \mathrm{H}, \mathrm{Ar}-\mathrm{H}_{(\mathrm{Bn})}\right), 7.38-7.32\left(\mathrm{~m}, 3 \mathrm{H}, \mathrm{Ar}-\mathrm{H}_{(\mathrm{Bn})}\right), 7.29-7.24$ $(\mathrm{m}, 1 \mathrm{H}, \mathrm{Ar}-\mathrm{H}), 7.17(\mathrm{td}, J=7.7,1.3 \mathrm{~Hz}, 1 \mathrm{H}, \mathrm{Ar}-\mathrm{H}), 6.98(\mathrm{td}, J=$ 7.4, 1.0 Hz, 1H, Ar-H), 6.77-6.73 (m, 1H, Ar-H), 6.26 (s, 1H, OH), $4.93\left(\mathrm{~d}, J=16.1 \mathrm{~Hz}, 1 \mathrm{H}, \mathrm{Ph}-\mathrm{CH}_{2(\mathrm{a})}\right), 4.85$ (d, $J=16.0 \mathrm{~Hz}, 1 \mathrm{H}, \mathrm{Ph}-$ $\mathrm{CH}_{2(\mathrm{~b})}$ ), 3.47 (d, $\left.J=16.9 \mathrm{~Hz}, 1 \mathrm{H}, \mathrm{CH}_{2(\mathrm{a})}\right), 3.21$ (d, $J=16.9 \mathrm{~Hz}, 1 \mathrm{H}$, $\left.\mathrm{CH}_{2(\mathrm{~b})}\right), 2.04\left(\mathrm{~s}, 3 \mathrm{H}, \mathrm{CH}_{3}\right) ;{ }^{13} \mathrm{C}-\mathrm{NMR}$ (126 MHz, DMSO- $\left.d_{6}\right)$ : $\delta(\mathrm{ppm})=205.32,176.75,143.18,136.40,130.99,129.03,128.49$, 127.26, 127.23, 123.45, 122.07, 108.99, 72.41, 50.36, 42.73, 30.44. All the analytical data are well in agreement with the reported literature. ${ }^{67}$

(S)-1-(2-Bromoethyl)-3-hydroxy-3-(2-oxopropyl)indolin-2-one (3l). 1-(2-Bromoethyl)isatin 11 (50.8 mg, $0.2 \mathrm{mmol})$ and acetone 2a (581.0 $\mathrm{mg}, 10.0 \mathrm{mmol})$ were reacted according to the GP1 to yield product 31 as pale yellow solid; m.p.:161-162 ${ }^{\circ} \mathrm{C}$; isolated yield (61.8 mg, 99\%). Enantiomeric excess (ee) was determined by chiral HPLC [Daicel Chiralpak AD-H column], 90.0\% $n$ -

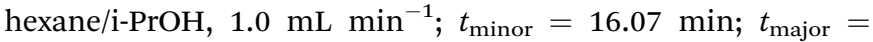
$17.39 \mathrm{~min} ; \lambda=254 \mathrm{~nm} ; 71 \%$ ee; $[\alpha]_{\mathrm{D}}^{20}=-19.86^{\circ}\left(c 0.04, \mathrm{CH}_{3} \mathrm{OH}\right)$; IR (KBr): 3350, 2925, 2853, 1709, 1610, 1488, 1469, 1454, 1432, 1416, 1375, 1359, 1336, 1183, 1179, 1163, 1132, 1006, 795, 751, 736, 708, 697, 563, 496, 476, $455 \mathrm{~cm}^{-1}$; ${ }^{1} \mathrm{H}-\mathrm{NMR}(500 \mathrm{MHz}$, DMSO- $\left.d_{6}\right): \delta(\mathrm{ppm})=7.32(\mathrm{dt}, J=7.3,0.9 \mathrm{~Hz}, 1 \mathrm{H}, \mathrm{Ar}-\mathrm{H}), 7.29-$ 7.26 (m, 1H, Ar-H), 7.11 (dt, J= 7.8, 0.8 Hz, 1H, Ar-H), 7.02-6.99 (m, 1H, Ar-H), 6.14 (s, 1H, OH), 4.08-4.05 (m, 2H, $\left.\mathrm{NCH}_{2}\right), 3.63$ (td, $\left.J=7.1,3.5 \mathrm{~Hz}, 2 \mathrm{H}, \mathrm{CH}_{2}-\mathrm{Br}\right), 3.36$ (d, $J=16.9 \mathrm{~Hz}, 1 \mathrm{H}, \mathrm{CH}_{2(\mathrm{a})}$ ), 3.08 (d, $\left.J=16.9 \mathrm{~Hz}, 1 \mathrm{H}, \mathrm{CH}_{2(\mathrm{~b})}\right), 2.00\left(\mathrm{~s}, 3 \mathrm{H}, \mathrm{CH}_{3}\right) ;{ }^{13} \mathrm{C}-\mathrm{NMR}(126$ $\left.\mathrm{MHz}, \mathrm{DMSO}-d_{6}\right): \delta(\mathrm{ppm})=205.24,176.69,142.68,130.70$, 129.17, 123.63, 122.16, 108.70, 72.25, 50.66, 40.97, 30.45, 28.66; LC/MS (ESI): found 390.01 $\left[\mathrm{M}\left({ }^{79} \mathrm{Br}\right)+\mathrm{H}\right]^{+} ; 391.90\left[\mathrm{M}\left({ }^{81} \mathrm{Br}\right)+\mathrm{H}\right]^{+}$, $\mathrm{C}_{13} \mathrm{H}_{13} \mathrm{Br}_{2} \mathrm{NO}_{3}$ requires 388.93; anal. calcd for $\mathrm{C}_{13} \mathrm{H}_{13} \mathrm{Br}_{2} \mathrm{NO}_{3}: \mathrm{C}$, 39.93; H, 3.35; N, 3.58; found: C, 40.14; H, 3.27; N, 3.49.

(S)-5-Bromo-3-hydroxy-3-(2-oxo-2-phenylethyl)indolin-2-one (3m). 5-Bromoisatin 1a (45.2 mg, $0.2 \mathrm{mmol})$ and acetophenone $2 \mathbf{b}(240.0 \mathrm{mg}, 2.0 \mathrm{mmol})$ were reacted according to the GP1 to yield product $3 \mathrm{~m}$ as white solid; m.p.:179-180 ${ }^{\circ} \mathrm{C}$; isolated yield (64.4 mg, 93\%). Enantiomeric excess (ee) was determined by chiral HPLC [Daicel Chiralpak AD-H column], 80.0\% $n$-hexane/i-

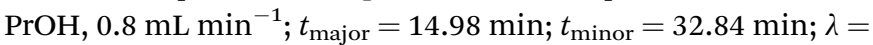
$254 \mathrm{~nm} ; 77 \%$ ee; $[\alpha]_{\mathrm{D}}^{20}=-55.21^{\circ}\left(c 0.05, \mathrm{CH}_{3} \mathrm{OH}\right)$; IR $(\mathrm{KBr}): 3350$, 3218, 1731, 1698, 1672, 1617, 1595, 1472, 1448, 1402, 1352, 1278, 1176, 1094, 1065, 991, 880, 824, 764, 686, 637, 591, 534, $478 \mathrm{~cm}^{-1} ;{ }^{1} \mathrm{H}-\mathrm{NMR}\left(500 \mathrm{MHz}, \mathrm{DMSO}-d_{6}\right): \delta(\mathrm{ppm})=10.44(\mathrm{~s}$, $1 \mathrm{H}, \mathrm{NH}), 7.89$ (d, $J=7.6 \mathrm{~Hz}, 2 \mathrm{H}, \mathrm{Ar}-\mathrm{H}), 7.63$ (t, $J=7.5 \mathrm{~Hz}, 1 \mathrm{H}$, $\mathrm{Ar}-\mathrm{H}$ ), 7.51 (d, $J=7.8 \mathrm{~Hz}, 3 \mathrm{H}, \mathrm{Ar}-\mathrm{H}), 7.35$ (d, $J=8.3 \mathrm{~Hz}, 1 \mathrm{H}, \mathrm{Ar}-$ $\mathrm{H}), 6.80(\mathrm{~d}, J=8.3 \mathrm{~Hz}, 1 \mathrm{H}, \mathrm{Ar}-\mathrm{H}), 6.23(\mathrm{~s}, 1 \mathrm{H}, \mathrm{OH}), 4.17$ (d, $J=$ $\left.17.9 \mathrm{~Hz}, 1 \mathrm{H}, \mathrm{CH}_{2(\mathrm{a})}\right), 3.65$ (d, $\left.J=18.1 \mathrm{~Hz}, 1 \mathrm{H}, \mathrm{CH}_{2(\mathrm{~b})}\right)$; ${ }^{13} \mathrm{C}-\mathrm{NMR}$ $\left(126 \mathrm{MHz}, \mathrm{DMSO}-d_{6}\right): \delta(\mathrm{ppm})=196.64,178.00,142.38,135.95$, 
134.42, 133.59, 131.55, 128.78, 127.98, 126.71, 112.94, 111.43, 73.05, 45.77; LC/MS (ESI): found $346.1\left[\mathrm{M}\left({ }^{79} \mathrm{Br}\right)+\mathrm{H}\right]^{+} ; 348.1$ $\left[\mathrm{M}\left({ }^{81} \mathrm{Br}\right)+\mathrm{H}\right]^{+}, \mathrm{C}_{16} \mathrm{H}_{12} \mathrm{BrNO}_{3}$ requires 345.0 ; anal. calcd for $\mathrm{C}_{16} \mathrm{H}_{12} \mathrm{BrNO}_{3}$ : C, 55.51; H, 3.49; N, 4.05; found: C, 55.43; H, $3.44 ; \mathrm{N}, 4.13$.

(S)-5-Bromo-3-hydroxy-3-(2-(2-nitrophenyl)-2-oxoethyl)indolin2-one (3n). 5-Bromoisatin 1a (45.2 mg, $0.2 \mathrm{mmol})$ and 1-(2nitrophenyl)ethan-1-one $2 \mathrm{c}(330.3 \mathrm{mg}, 2.0 \mathrm{mmol})$ were reacted according to the GP1 to yield product $3 \mathbf{n}$ as white solid; m.p.:188-190 ${ }^{\circ} \mathrm{C}$; isolated yield (75.1 mg, 96\%). Enantiomeric excess (ee) was determined by chiral HPLC [Daicel Chiralpak $\mathrm{AD}-\mathrm{H}$ column], 70.0\% $n$-hexane $/ \mathrm{i}-\mathrm{PrOH}, 1.0 \mathrm{~mL} \mathrm{~min}{ }^{-1} ; t_{\text {major }}=$ $11.98 \mathrm{~min} ; t_{\text {minor }}=31.04 \mathrm{~min} ; \lambda=254 \mathrm{~nm} ; 70 \%$ ee; $[\alpha]_{\mathrm{D}}^{20}=$ $-75.51^{\circ}$ (c 0.08, $\left.\mathrm{CH}_{3} \mathrm{OH}\right)$; IR (KBr): 3337, 3390, 1738, 1702, 1615, 1573, 1530, 1471, 1441, 1388, 1314, 1216, 1180, 1130, 1059, 998, 895, 838, 754, 744, 731, 699, 672, $542 \mathrm{~cm}^{-1} ;{ }^{1} \mathrm{H}-\mathrm{NMR}(500 \mathrm{MHz}$, DMSO- $\left.d_{6}\right): \delta(\mathrm{ppm})=10.46(\mathrm{~s}, 1 \mathrm{H}, \mathrm{NH}), 8.04(\mathrm{~d}, J=8.0 \mathrm{~Hz}, 1 \mathrm{H}$, $\mathrm{Ar}-\mathrm{H}), 7.78$ (dt, $J=32.4,7.8 \mathrm{~Hz}, 2 \mathrm{H}, \mathrm{Ar}-\mathrm{H}), 7.60$ (d, $J=7.6 \mathrm{~Hz}$, $1 \mathrm{H}, \mathrm{Ar}-\mathrm{H}), 7.54$ (s, 1H, Ar-H), 7.38 (d, J=8.3 Hz, 1H, Ar-H), 6.78 (d, $J=8.4 \mathrm{~Hz}, 1 \mathrm{H}, \mathrm{Ar}-\mathrm{H}), 6.30(\mathrm{~s}, 1 \mathrm{H}, \mathrm{OH}), 3.91$ (d, $J=17.5 \mathrm{~Hz}$, $\left.1 \mathrm{H}, \mathrm{CH}_{2(\mathrm{a})}\right), 3.53\left(\mathrm{~d}, J=17.6 \mathrm{~Hz}, 1 \mathrm{H}, \mathrm{CH}_{2(\mathrm{~b})}\right) ;{ }^{13} \mathrm{C}-\mathrm{NMR}(126 \mathrm{MHz}$, DMSO- $\left.d_{6}\right): \delta(\mathrm{ppm})=198.01,177.39,146.19,142.04,134.51$, 133.97, 133.37, 132.14, 131.82, 128.53, 127.29, 124.27, 113.11, 111.50, 72.87, 48.42; LC/MS (ESI): found $391.1\left[\mathrm{M}\left({ }^{79} \mathrm{Br}\right)+\mathrm{H}\right]^{+}$; $393.1\left[\mathrm{M}\left({ }^{81} \mathrm{Br}\right)+\mathrm{H}\right]^{+}, \mathrm{C}_{16} \mathrm{H}_{11} \mathrm{BrN}_{2} \mathrm{O}_{5}$ requires 389.99; anal. calcd for $\mathrm{C}_{16} \mathrm{H}_{11} \mathrm{BrN}_{2} \mathrm{O}_{5}$ : C, 49.13; H, 2.83; N, 7.16; found: C, 49.27; H, 2.89; N, 7.09.

(S)-5-Bromo-3-(2-(4-fluorophenyl)-2-oxoethyl)-3-hydroxyindolin2-one (3o). 5-Bromoisatin 1a (45.2 mg, $0.2 \mathrm{mmol})$ and 1-(4-fluorophenyl)ethan-1-one $2 \mathrm{~d}(276.3 \mathrm{mg}, 2.0 \mathrm{mmol})$ were reacted according to the GP1 to yield product 30 as white solid; m.p.:186-187 ${ }^{\circ} \mathrm{C}$; isolated yield (67.7 mg, 93\%). Enantiomeric excess (ee) was determined by chiral HPLC [Daicel Chiralpak $\mathrm{AD}-\mathrm{H}$ column], $70.0 \% n$-hexane $/ \mathrm{i}-\mathrm{PrOH}, 1.0 \mathrm{~mL} \mathrm{~min}^{-1} ; t_{\text {major }}=$ $8.96 \mathrm{~min} ; t_{\text {minor }}=17.02 \mathrm{~min} ; \lambda=254 \mathrm{~nm} ; 81 \%$ ee; $[\alpha]_{\mathrm{D}}^{20}=-5.90^{\circ}$ (c $\left.0.04, \mathrm{CH}_{3} \mathrm{OH}\right)$; IR (KBr): 3235, 1698, 1686, 1619, 1600, 1507, 1473, 1449, 1409, 1348, 1234, 1181, 1166, 1072, 991, 827, 732, $591,559 \mathrm{~cm}^{-1} ;{ }^{1} \mathrm{H}-\mathrm{NMR}\left(500 \mathrm{MHz}, \mathrm{DMSO}-d_{6}\right): \delta(\mathrm{ppm})=10.44$ $(\mathrm{s}, 1 \mathrm{H}, \mathrm{NH}), 7.98(\mathrm{~s}, 2 \mathrm{H}, \mathrm{Ar}-\mathrm{H}), 7.51(\mathrm{~s}, 1 \mathrm{H}, \mathrm{Ar}-\mathrm{H}), 7.38-7.25(\mathrm{~m}$, $3 \mathrm{H}, \mathrm{Ar}-\mathrm{H}), 6.86-6.72(\mathrm{~m}, 1 \mathrm{H}, \mathrm{Ar}-\mathrm{H}), 6.24(\mathrm{~s}, 1 \mathrm{H}, \mathrm{OH}), 4.16(\mathrm{~d}, J=$ $\left.17.9 \mathrm{~Hz}, 1 \mathrm{H}, \mathrm{CH}_{2(\mathrm{a})}\right), 3.63$ (d, $\left.J=18.2 \mathrm{~Hz}, 1 \mathrm{H}, \mathrm{CH}_{2(\mathrm{~b})}\right) ;{ }^{13} \mathrm{C}-\mathrm{NMR}$ $\left(126 \mathrm{MHz}, \mathrm{DMSO}-d_{6}\right): \delta(\mathrm{ppm})=195.28,177.98,166.25,164.24$, $142.35,134.36,132.76,131.58,131.26,131.13,131.06,126.75$, 115.88, 115.71, 112.96, 111.45, 73.06, 45.72; LC/MS (ESI): found $364.1\left[\mathrm{M}\left({ }^{79} \mathrm{Br}\right)+\mathrm{H}\right]^{+} ; 366.1\left[\mathrm{M}\left({ }^{81} \mathrm{Br}\right)+\mathrm{H}\right]^{+}, \mathrm{C}_{16} \mathrm{H}_{11} \mathrm{BrFNO}_{3}$ requires 362.99; anal. calcd for $\mathrm{C}_{16} \mathrm{H}_{11} \mathrm{BrFNO}_{3}$ : C, 52.77; $\mathrm{H}, 3.04$; 3.85; found: C, 52.61; H, 3.18; N, 3.95.

(S)-5-Bromo-3-(2-(4-bromophenyl)-2-oxoethyl)-3-hydroxyindolin2-one (3p). 5-Bromoisatin 1a (45.2 mg, $0.2 \mathrm{mmol})$ and 1-(4-bromophenyl)ethan-1-one $2 \mathrm{e}(398.1,2.0 \mathrm{mmol})$ were reacted according to the GP1 to yield product $3 \mathbf{p}$ as white solid; m.p.:184-185 ${ }^{\circ} \mathrm{C}$; isolated yield (78.2 mg, 92\%). Enantiomeric excess (ee) was determined by chiral HPLC [Daicel Chiralpak $\mathrm{AD}-\mathrm{H}$ column], 70.0\% $n$-hexane $/ \mathrm{i}-\mathrm{PrOH}, 1.0 \mathrm{~mL} \mathrm{~min}^{-1} ; t_{\text {major }}=$ $12.55 \mathrm{~min} ; t_{\text {minor }}=32.98 \mathrm{~min} ; \lambda=254 \mathrm{~nm} ; 81 \%$ ee; $[\alpha]_{\mathrm{D}}^{20}=$ $-21.79^{\circ}$ (c 0.03, $\mathrm{CH}_{3} \mathrm{OH}$ ); IR (KBr): 3188, 1713, 1699, 1618, 1587, 1472, 1448, 1397, 1344, 1215, 1183, 1069, 1008, 989, 827, 810,
733, 647, $556 \mathrm{~cm}^{-1} ;{ }^{1} \mathrm{H}-\mathrm{NMR}\left(500 \mathrm{MHz}, \mathrm{DMSO}-d_{6}\right): \delta(\mathrm{ppm})=$ 10.45 (s, 1H, NH), 7.76 (d, J=54.0 Hz, 4H, Ar-H), 7.50 (s, 1H, Ar$\mathrm{H}), 7.34$ (s, 1H, Ar-H), 6.89-6.70 (m, 1H, Ar-H), $6.24(\mathrm{~s}, 1 \mathrm{H}, \mathrm{OH})$, 4.15 (d, $\left.J=18.1 \mathrm{~Hz}, 1 \mathrm{H}, \mathrm{CH}_{2(\mathrm{a})}\right), 3.61$ (d, $J=18.2 \mathrm{~Hz}, 1 \mathrm{H}, \mathrm{CH}_{2(\mathrm{~b})}$ ); ${ }^{13} \mathrm{C}-\mathrm{NMR}\left(126 \mathrm{MHz}, \mathrm{DMSO}-d_{6}\right): \delta(\mathrm{ppm})=195.91,177.90$, $142.30,134.94,134.25,131.84,131.60,130.05,127.77,126.79$, 112.97, 111.45, 73.02, 45.72; LC/MS (ESI): found $423.9\left[\mathrm{M}\left({ }^{79} \mathrm{Br}\right)+\right.$ $\mathrm{H}]^{+}$; $425.9\left[\mathrm{M}\left({ }^{81} \mathrm{Br}\right)+\mathrm{H}\right]^{+}, \mathrm{C}_{16} \mathrm{H}_{11} \mathrm{Br}_{2} \mathrm{NO}_{3}$ requires 422.91; anal. calcd for $\mathrm{C}_{16} \mathrm{H}_{11} \mathrm{Br}_{2} \mathrm{NO}_{3}$ : C, 45.21; $\mathrm{H}, 2.61 ; \mathrm{N}, 3.30$; found: $\mathrm{C}$, 42.16; H, 2.53; N, 3.27.

(S)-5-Bromo-3-hydroxy-3-(2-(4-nitrophenyl)-2-oxoethyl)indolin2-one (3q). 5-Bromoisatin 1a $(45.2 \mathrm{mg}, 0.2 \mathrm{mmol})$ and 1-(4nitrophenyl)ethan-1-one $2 f(330.3,2.0 \mathrm{mmol})$ were reacted according to the GP1 to yield product $\mathbf{3 q}$ as white solid; m.p.:187-188 ${ }^{\circ} \mathrm{C}$; isolated yield (68.8 mg, 88\%). Enantiomeric excess (ee) was determined by chiral HPLC [Daicel Chiralpak AD-H column], 70.0\% $n$-hexane/i-PrOH, $1.0 \mathrm{~mL} \mathrm{~min}^{-1} ; t_{\text {major }}=$ $22.05 \mathrm{~min} ; t_{\text {minor }}=30.35 \mathrm{~min} ; \lambda=254 \mathrm{~nm} ; 54 \%$ ee; $[\alpha]_{\mathrm{D}}^{20}=$ $-11.43^{\circ}$ (c 0.04, $\mathrm{CH}_{3} \mathrm{OH}$ ); IR (KBr): 3196, 1654, 1618, 1528, 1478, 1447, 1343, 1249, 1209, 1183, 1123, 1060, 1000, 903, 895, 855, 824, 742, 644, 595, $535 \mathrm{~cm}^{-1}$; ${ }^{1} \mathrm{H}-\mathrm{NMR}$ (500 MHz, DMSO- $d_{6}$ ): $\delta(\mathrm{ppm})=10.48(\mathrm{~s}, 1 \mathrm{H}, \mathrm{NH}), 8.31(\mathrm{~d}, J=8.8 \mathrm{~Hz}, 2 \mathrm{H}, \mathrm{Ar}-\mathrm{H}), 8.12$ $(\mathrm{d}, J=8.8 \mathrm{~Hz}, 2 \mathrm{H}, \mathrm{Ar}-\mathrm{H}), 7.52(\mathrm{~d}, J=2.1 \mathrm{~Hz}, 1 \mathrm{H}, \mathrm{Ar}-\mathrm{H}), 7.36$ (dd, $J=8.2,2.1 \mathrm{~Hz}, 1 \mathrm{H}, \mathrm{Ar}-\mathrm{H}), 6.79$ (d, $J=8.2 \mathrm{~Hz}, 1 \mathrm{H}, \mathrm{Ar}-\mathrm{H}), 6.30$ (s, $1 \mathrm{H}, \mathrm{OH}), 4.23$ (d, $\left.J=18.0 \mathrm{~Hz}, 1 \mathrm{H}, \mathrm{CH}_{2(\mathrm{a})}\right), 3.70$ (d, $J=17.9 \mathrm{~Hz}$, $\left.1 \mathrm{H}, \mathrm{CH}_{2(\mathrm{~b})}\right) ;{ }^{13} \mathrm{C}-\mathrm{NMR}\left(126 \mathrm{MHz}, \mathrm{DMSO}-d_{6}\right): \delta(\mathrm{ppm})=196.01$, $177.77,150.10,142.24,140.46,134.02$, 131.71, 129.53, 126.93, 123.88, 113.03, 111.51, 73.04, 46.23; LC/MS (ESI): found 391.1 $\left[\mathrm{M}\left({ }^{79} \mathrm{Br}\right)+\mathrm{H}\right]^{+} ; 393.1\left[\mathrm{M}\left({ }^{81} \mathrm{Br}\right)+\mathrm{H}\right]^{+}, \mathrm{C}_{16} \mathrm{H}_{11} \mathrm{BrN}_{2} \mathrm{O}_{5}$ requires 389.99; anal. calcd for $\mathrm{C}_{16} \mathrm{H}_{11} \mathrm{BrN}_{2} \mathrm{O}_{5}$ : C, 49.13; H, 2.83; N, 7.16; found: C, 49.23; H, 2.69; N, 7.24.

(S)-5-Bromo-3-hydroxy-3-(2-(4-hydroxyphenyl)-2-oxoethyl) indolin-2-one (3r). 5-Bromoisatin $1 \mathrm{a}(45.2 \mathrm{mg}, 0.2 \mathrm{mmol})$ and 1(4-hydroxyphenyl)ethan-1-one $2 \mathrm{~g}(272.3 \mathrm{mg}, 2.0 \mathrm{mmol})$ were reacted according to the GP1 to yield product $3 \mathbf{r}$ as white solid; M.P.:191-192 ${ }^{\circ} \mathrm{C}$; isolated yield (58.7 mg, 81\%). Enantiomeric excess (ee) was determined by chiral HPLC [Daicel Chiralpak AD-H column], 80.0\% $n$-hexane/i-PrOH, $1.0 \mathrm{~mL} \mathrm{~min}^{-1}$; $t_{\text {major }}=9.31 \mathrm{~min} ; t_{\text {minor }}=23.06 \mathrm{~min} ; \lambda=254 \mathrm{~nm} ; 50 \%$ ee; $[\alpha]_{\mathrm{D}}^{20}=-78.91^{\circ}\left(c 0.04, \mathrm{CH}_{3} \mathrm{OH}\right)$; IR $(\mathrm{KBr}): 3230,1714,1710$, 1698, 1651, 1619, 1605, 1582, 1479, 1446, 1356, 1290, 1225, 1182, 1171, 1063, 997, 825, 734, 612, 592, 558, $\mathrm{cm}^{-1} ;{ }^{1} \mathrm{H}-\mathrm{NMR}$ $\left(500 \mathrm{MHz}, \mathrm{DMSO}-d_{6}\right): \delta(\mathrm{ppm})=10.42(\mathrm{~s}, 1 \mathrm{H}, \mathrm{NH}), 10.37(\mathrm{~s}$, $1 \mathrm{H}, \mathrm{OH}), 7.76(\mathrm{~d}, J=8.8 \mathrm{~Hz}, 2 \mathrm{H}, \mathrm{Ar}-\mathrm{H}), 7.47(\mathrm{~d}, J=2.1 \mathrm{~Hz}, 1 \mathrm{H}$, $\mathrm{Ar}-\mathrm{H}), 7.33$ (dd, $J=8.2,2.1 \mathrm{~Hz}, 1 \mathrm{H}, \mathrm{Ar}-\mathrm{H}), 6.82(\mathrm{~d}, J=8.8 \mathrm{~Hz}$, $2 \mathrm{H}, \mathrm{Ar}-\mathrm{H}), 6.77$ (d, J = 8.3 Hz, 1H, Ar-H), 6.15 (s, 1H, OH), 4.04 $\left(\mathrm{d}, J=17.6 \mathrm{~Hz}, 1 \mathrm{H}, \mathrm{CH}_{2(\mathrm{a})}\right), 3.52\left(\mathrm{~d}, J=17.7 \mathrm{~Hz}, 1 \mathrm{H}, \mathrm{CH}_{2(\mathrm{~b})}\right) ;{ }^{13} \mathrm{C}-$ NMR (126 MHz, DMSO- $\left.d_{6}\right): \delta(\mathrm{ppm})=194.61,178.13,162.35$, 142.42, 134.66, 131.45, 130.59, 127.71, 126.59, 115.27, 112.86, 111.37, 73.12, 45.31; LC/MS (ESI): found $362.1\left[\mathrm{M}\left({ }^{79} \mathrm{Br}\right)+\mathrm{H}\right]^{+}$; $364.1\left[\mathrm{M}\left({ }^{81} \mathrm{Br}\right)+\mathrm{H}\right]^{+}, \mathrm{C}_{16} \mathrm{H}_{12} \mathrm{BrNO}_{4}$ requires 360.99; anal. calcd for $\mathrm{C}_{16} \mathrm{H}_{12} \mathrm{BrNO}_{4}$ : C, 53.06; H, 3.34; N, 3.87; found: C, 52.92; H, 3.46 ; N, 3.97 .

(S)-5-Bromo-3-hydroxy-3-((R)-2-oxocyclohexyl)indolin-2-one (3s). 5-Bromoisatin 1a $(45.2 \mathrm{mg}, 0.2 \mathrm{mmol})$ and cyclohexanone $2 \mathrm{~h}(196.3 \mathrm{mg}, 0.21 \mathrm{~mL}, 2.0 \mathrm{mmol})$ were reacted according to the GP1 to yield product $3 \mathrm{~s}$ as white solid; m.p.: $224-225{ }^{\circ} \mathrm{C}$; 
isolated yield (64.2 $\mathrm{mg}, 99 \%)$, syn/anti $=(88: 12)$. Enantiomeric excess (ee) of (syn, major) was determined by chiral HPLC [Daicel Chiralpak AD-H column], 92.0\% $n$-hexane/i-PrOH, 0.8 $\mathrm{mL} \min ^{-1} ; t_{\text {syn-major }}=53.32 \mathrm{~min} ; t_{\text {syn-minor }}=74.56 \mathrm{~min} ; t_{\text {anti- }}$ major $=63.64 \mathrm{~min} ; \lambda=254 \mathrm{~nm} ; \mathrm{syn} / \mathrm{anti}=88: 12$; Enantiomeric excess (ee) of syn diastereomers $=85 \% ;[\alpha]_{\mathrm{D}}^{20}=-46.97^{\circ}(c 0.02$, $\left.\mathrm{CH}_{3} \mathrm{OH}\right)$; [ref. 72. $[\alpha]_{\mathrm{D}}^{25}=-16.3^{\circ}(c$ 0.1, MeOH$\left.)\right] ;{ }^{1} \mathrm{H}-\mathrm{NMR}(500$ MHz, DMSO- $\left.d_{6}\right): \delta(\mathrm{ppm})=10.37(\mathrm{~s}, 1 \mathrm{H}, \mathrm{NH}), 7.45-7.25(\mathrm{~m}, 2 \mathrm{H}$, $\mathrm{Ar}-\mathrm{H}), 6.77(\mathrm{~s}, 1 \mathrm{H}, \mathrm{Ar}-\mathrm{H}), 6.01(\mathrm{~s}, 1 \mathrm{H}, \mathrm{OH}), 3.10$ (dt, $J=8.0$, $6.1 \mathrm{~Hz}, 1 \mathrm{H}, \mathrm{COCH}), 2.59-2.50\left(\mathrm{~m}, 1 \mathrm{H}, \mathrm{COCH}_{2}\right), 2.33-2.30(\mathrm{~m}$, $\left.1 \mathrm{H}, \mathrm{COCH}_{2}\right), 2.06-1.51\left(\mathrm{~m}, 6 \mathrm{H},\left(\mathrm{CH}_{2}\right)_{3}\right) ;{ }^{13} \mathrm{C}-\mathrm{NMR}(126 \mathrm{MHz}$, DMSO- $\left.d_{6}\right): \delta(\mathrm{ppm})=209.34,178.25,142.79,133.34,131.30$, 127.45, 112.52, 111.40, 73.93, 57.43, 41.45, 26.72, 26.66, 24.44. All the analytical data are well in agreement with the reported literature. $^{72}$

\section{General procedure (GP2) for synthesis of asymmetric spiro [4H-pyran-3,3-oxindole] derivatives (6a-1) of three components with one pot}

GP2. A small vial $(8 \mathrm{~mL})$ under nitrogen atmosphere were charged with ligand L1 (8.2 $\mathrm{mg}, 0.02 \mathrm{mmol}, 10 \mathrm{~mol} \%$ ), $\mathrm{Cu}(\mathrm{OAc})_{2} \cdot \mathrm{H}_{2} \mathrm{O}(12.0 \mathrm{mg}, 0.06 \mathrm{mmol}, 30 \mathrm{~mol} \%)$ and tetrahydrofuran (THF) $(3 \mathrm{~mL})$. The solution was stirred for $2 \mathrm{~h}$ at room temperature to obtain a blue solution of $\mathbf{L 1}-\mathrm{Cu}(\mathrm{OAc})_{2} \cdot \mathrm{H}_{2} \mathrm{O}$ complex. Then, isatins $\mathbf{1 a}-\mathbf{1}(0.2 \mathrm{mmol})$ and malononitrile 4 (13.2 $\mathrm{mg}, 0.2 \mathrm{mmol}$ ) were then added to blue coloured solution and stirred for $10 \mathrm{~min}$ at room temperature followed by addition of ethylacetoacetate $5(26.0 \mathrm{mg}, 0.2 \mathrm{mmol})$ and the reaction mixture was left stirring for another 5-15 h. After that the solvent were removed under reduced pressure, the residue was directly purified on 100 mesh silica gel columns, eluting by EtOAc/petroleum ether (60-80\%) to obtain the corresponding chiral spirooxindole products $\mathbf{6 a - 1}$.

Ethyl-(S)-2'-amino-5-bromo-3'-cyano-6'-methyl-2-oxospiro[indoline-3, $4^{\prime}$-pyran]-5'-carboxylate (6a). 5-Bromoisatin $1 \mathrm{a}(45.2 \mathrm{mg}$, $0.2 \mathrm{mmol})$, malononitrile $4(13.2 \mathrm{mg}, 0.2 \mathrm{mmol})$ and ethylacetoacetate $5(26.0 \mathrm{mg}, 0.2 \mathrm{mmol})$ were reacted according to the GP2 to yield product $6 \mathbf{a}$ as white solid; m.p.: $259-260{ }^{\circ} \mathrm{C}$; isolated yield (80.8 mg, 98\%). Enantiomeric excess (ee) was determined by chiral HPLC [Daicel Chiralpak AD-H column], $90.0 \% n$-hexane/i-PrOH, $0.8 \mathrm{~mL} \mathrm{~min}^{-1} ; t_{\text {minor }}=38.79 \mathrm{~min} ; t_{\text {major }}$ $=41.37 \mathrm{~min} ; \lambda=254 \mathrm{~nm} ; 91 \%$ ee; $[\alpha]_{\mathrm{D}}^{20}=+8.62^{\circ}(c \quad 0.07$, $\left.\mathrm{CH}_{3} \mathrm{OH}\right)$; [ref. $97[\alpha]_{\mathrm{D}}^{24}=+34.3^{\circ}(c$ 1.0, MeOH$\left.)\right] ;{ }^{1} \mathrm{H}-\mathrm{NMR}(500$ MHz, DMSO- $\left.d_{6}\right): \delta(\mathrm{ppm})=10.55(\mathrm{~s}, 1 \mathrm{H}, \mathrm{NH}), 7.40-7.32(\mathrm{~m}, 1 \mathrm{H}$, $\mathrm{Ar}-\mathrm{H}$ ), 7.29 (s, 1H, Ar-H), 7.23 (s, 2H, $\mathrm{NH}_{2}$ ), 6.77 (d, $J=8.3 \mathrm{~Hz}$, $1 \mathrm{H}, \mathrm{Ar}-\mathrm{H}$ ), 3.82 (q, $\left.J=8.0 \mathrm{~Hz}, 2 \mathrm{H}, \mathrm{CH}_{2} \mathrm{CH}_{3}\right), 2.33\left(\mathrm{~s}, 3 \mathrm{H}, \mathrm{CH}_{3}\right)$, $0.84\left(\mathrm{t}, J=7.4 \mathrm{~Hz}, 3 \mathrm{H}, \mathrm{CH}_{2} \mathrm{CH}_{3}\right) ;{ }^{13} \mathrm{C}-\mathrm{NMR}\left(126 \mathrm{MHz}\right.$, DMSO- $\left.d_{6}\right)$ : $\delta(\mathrm{ppm})=178.27,164.37,159.56,158.91,141.44,137.23,131.29$, 126.27, 117.38, 113.45, 111.31, 103.72, 60.42, 55.94, 49.24, $18.80,13.06$. All the analytical data are well in agreement with the reported literature. ${ }^{97}$

Ethyl-(S)-2'-amino-3'-cyano-6'-methyl-2-oxospiro[indoline-3, $4^{\prime}$ pyran]-5'-carboxylate (6b). Isatin $\mathbf{1 b}(29.4 \mathrm{mg}, 0.2 \mathrm{mmol})$, malononitrile $4(13.2 \mathrm{mg}, 0.2 \mathrm{mmol})$ and ethylacetoacetate 5 (26.0 $\mathrm{mg}, 0.2 \mathrm{mmol}$ ) were reacted according to the GP2 to yield product $6 \mathbf{b}$ as white solid; m.p.: $253-254{ }^{\circ} \mathrm{C}$; isolated yield
(64.4 mg, 99\%). Enantiomeric excess (ee) was determined by chiral HPLC [Daicel Chiralpak AD-H column], 85.0\% $n$-hexane/i-

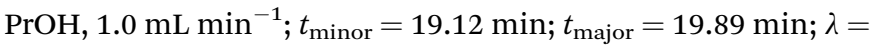
$254 \mathrm{~nm} ; 42 \%$ ee; $[\alpha]_{\mathrm{D}}^{20}=+21.83^{\circ}\left(c 0.05, \mathrm{CH}_{3} \mathrm{OH}\right) ;\left[\right.$ ref. $97[\alpha]_{\mathrm{D}}^{24}=$ $+20.4^{\circ}(c$ 1.4, MeOH$\left.)\right] ;{ }^{1} \mathrm{H}-\mathrm{NMR}\left(500 \mathrm{MHz}, \mathrm{DMSO}-d_{6}\right): \delta(\mathrm{ppm})=$ 10.39 (s, 1H, NH), 7.18 (td, $J=7.6,1.3 \mathrm{~Hz}, 1 \mathrm{H}, \mathrm{Ar}-\mathrm{H}), 7.14(\mathrm{~s}, 2 \mathrm{H}$, $\mathrm{NH}_{2}$ ), 7.05 (dd, $\left.J=7.4,1.2 \mathrm{~Hz}, 1 \mathrm{H}, \mathrm{Ar}-\mathrm{H}\right), 6.93(\mathrm{td}, J=7.5$, $1.0 \mathrm{~Hz}, 1 \mathrm{H}, \mathrm{Ar}-\mathrm{H}$ ), 6.79 (dt, $J=7.7,0.8 \mathrm{~Hz}, 1 \mathrm{H}, \mathrm{Ar}-\mathrm{H}), 3.81-3.72$ $\left(\mathrm{m}, 2 \mathrm{H}, \mathrm{CH}_{2} \mathrm{CH}_{3}\right), 2.31\left(\mathrm{~s}, 3 \mathrm{H}, \mathrm{CH}_{3}\right), 0.78(\mathrm{t}, J=7.1 \mathrm{~Hz}, 3 \mathrm{H}$, $\left.\mathrm{CH}_{2} \mathrm{CH}_{3}\right) ;{ }^{13} \mathrm{C}-\mathrm{NMR}\left(126 \mathrm{MHz}, \mathrm{DMSO}-d_{6}\right): \delta(\mathrm{ppm})=178.60$, 164.52, 158.95, 158.52, 142.17, 134.56, 128.56, 123.41, 121.86, $117.51,109.33,104.67,60.26,56.52,48.96,18.57,12.99$. All the analytical data are well in agreement with the reported literature. ${ }^{97}$

Ethyl-(S)-2' -amino-5-chloro-3'-cyano-6'-methyl-2-oxospiro[indoline-3,4'-pyran]-5'-carboxylate (6c). 5-Chloroisatin 1c $(36.3 \mathrm{mg}$, $0.2 \mathrm{mmol})$, malononitrile $4(13.2 \mathrm{mg}, 0.2 \mathrm{mmol})$ and ethylacetoacetate $5(26.0 \mathrm{mg}, 0.2 \mathrm{mmol})$ were reacted according to the GP2 to yield product $6 \mathrm{c}$ as white solid; m.p.: $247-248{ }^{\circ} \mathrm{C}$; isolated yield (69.1 mg, 96\%). Enantiomeric excess (ee) was determined by chiral HPLC [Daicel Chiralpak AD-H column], $90.0 \%$-hexane $/ \mathrm{i}$-PrOH, $0.8 \mathrm{~mL} \mathrm{~min}^{-1} ; t_{\text {minor }}=36.52 \mathrm{~min} ; t_{\text {major }}$ $=40.92 \mathrm{~min} ; \lambda=254 \mathrm{~nm} ; 57 \%$ ee; $[\alpha]_{\mathrm{D}}^{20}=-31.08^{\circ}(c 0.05$, $\left.\mathrm{CH}_{3} \mathrm{OH}\right) ;\left[\right.$ ref. $97[\alpha]_{\mathrm{D}}^{24}=-21.7^{\circ}\left(c\right.$ 1.0, MeOH)]; ${ }^{1} \mathrm{H}-\mathrm{NMR}(500$ MHz, DMSO- $\left.d_{6}\right): \delta(\mathrm{ppm})=10.56(\mathrm{~s}, 1 \mathrm{H}, \mathrm{NH}), 7.25\left(\mathrm{~s}, 2 \mathrm{H}, \mathrm{NH}_{2}\right)$, 7.23 (dd, $J=8.2,2.2 \mathrm{~Hz}, \mathrm{Ar}-\mathrm{H}$ ), 7.19 (d, $J=2.2 \mathrm{~Hz}, 1 \mathrm{H}, \mathrm{Ar}-\mathrm{H}$ ), $6.81(\mathrm{~d}, J=8.2 \mathrm{~Hz}, 1 \mathrm{H}, \mathrm{Ar}-\mathrm{H}), 3.81\left(\mathrm{q}, J=7.1 \mathrm{~Hz}, 2 \mathrm{H}, \mathrm{CH}_{2} \mathrm{CH}_{3}\right.$ ), $2.33\left(\mathrm{~s}, 3 \mathrm{H}, \mathrm{CH}_{3}\right), 0.83\left(\mathrm{t}, J=7.1 \mathrm{~Hz}, \mathrm{CH}_{2} \mathrm{CH}_{3}\right) ;{ }^{13} \mathrm{C}-\mathrm{NMR}(126$ MHz, DMSO- $\left.d_{6}\right): \delta(\mathrm{ppm})=178.45,164.40,159.57,158.95$, 141.06, 136.87, 128.47, 125.83, 123.65, 117.44, 110.80, 103.75, $60.46,55.90,49.31,18.82,13.08$. All the analytical data are well in agreement with the reported literature. ${ }^{97}$

Ethyl-(S)-2'-amino-6-chloro-3'-cyano-6'-methyl-2-oxospiro[indoline-3,4'-pyran]-5'-carboxylate (6d). 6-Chloroisatin 1 d $(36.3 \mathrm{mg}$, $0.2 \mathrm{mmol})$, malononitrile $4(13.2 \mathrm{mg}, 0.2 \mathrm{mmol})$ and ethylacetoacetate $5(26.0 \mathrm{mg}, 0.2 \mathrm{mmol})$ were reacted according to the GP2 to yield product $\mathbf{6 d}$ as white solid; m.p.: $258-259{ }^{\circ} \mathrm{C}$; isolated yield (66.2 mg, 92\%). Enantiomeric excess (ee) was determined by chiral HPLC [Daicel Chiralpak AD-H column], $90.0 \% n$-hexane $/ \mathrm{i}$-PrOH, $0.8 \mathrm{~mL} \mathrm{~min}^{-1} ; t_{\text {minor }}=54.81 \mathrm{~min} ; t_{\text {major }}$ $=62.03 \mathrm{~min} ; \lambda=254 \mathrm{~nm} ; 47 \%$ ee; $[\alpha]_{\mathrm{D}}^{20}=+41.62^{\circ}(c 0.04$, $\mathrm{CH}_{3} \mathrm{OH}$ ); IR (KBr): 3382, 3317, 3201, 2988, 2205, 1720, 1706, $1655,1616,1595,1487,1455,1418,1379,1364,1322,1284$, 1250, 1223, 1182, 1132, 854, 808, 776, 745, 719, 687, 633, $531 \mathrm{~cm}^{-1} ;{ }^{1} \mathrm{H}-\mathrm{NMR}\left(500 \mathrm{MHz}, \mathrm{DMSO}-d_{6}\right): \delta(\mathrm{ppm})=10.59(\mathrm{~s}$, $1 \mathrm{H}, \mathrm{NH}), 7.24\left(\mathrm{~s}, 2 \mathrm{H}, \mathrm{NH}_{2}\right), 7.18(\mathrm{td}, J=7.6,1.3 \mathrm{~Hz}, 1 \mathrm{H}, \mathrm{Ar}-\mathrm{H})$, $7.14\left(\mathrm{~s}, 2 \mathrm{H}, \mathrm{NH}_{2}\right), 7.10$ (d, $\left.J=7.9 \mathrm{~Hz}, 1 \mathrm{H}, \mathrm{Ar}-\mathrm{H}\right), 6.98$ (dd, $J=7.9$, $1.9 \mathrm{~Hz}, 1 \mathrm{H}, \mathrm{Ar}-\mathrm{H}), 6.81$ (d, $J=1.9 \mathrm{~Hz}, 1 \mathrm{H}, \mathrm{Ar}-\mathrm{H}), 3.88-3.75(\mathrm{~m}$, $\left.2 \mathrm{H}, \mathrm{CH}_{2} \mathrm{CH}_{3}\right), 2.32\left(\mathrm{~s}, 3 \mathrm{H}, \mathrm{CH}_{3}\right), 0.84\left(\mathrm{t}, J=7.1 \mathrm{~Hz}, 3 \mathrm{H}, \mathrm{CH}_{2} \mathrm{CH}_{3}\right)$; ${ }^{13} \mathrm{C}-\mathrm{NMR}\left(126 \mathrm{MHz}, \mathrm{DMSO}-d_{6}\right): \delta(\mathrm{ppm})=178.62,164.40$, 159.20, 158.96, 143.69, 133.59, 132.74, 124.96, 121.63, 117.41, $109.40,104.04,60.48,56.08,48.75,18.74,13.11$. All the analytical data are well in agreement with the reported literature. ${ }^{97}$

Ethyl-(S)-2'-amino-3'-cyano-5-methoxy-6'-methyl-2-oxospiro [indoline-3,4'-pyran]-5'-carboxylate (6e). 5-Methoxyisatin $\mathbf{1 e}$ (35.4 mg, $0.2 \mathrm{mmol})$, malononitrile $4(13.2 \mathrm{mg}, 0.2 \mathrm{mmol})$ and ethylacetoacetate $5(26.0 \mathrm{mg}, 0.2 \mathrm{mmol})$ were reacted according 
to the GP2 to yield product $6 \mathrm{e}$ as white solid; m.p.: $249-250{ }^{\circ} \mathrm{C}$; isolated yield (66.1 mg, 93\%). Enantiomeric excess (ee) was determined by chiral HPLC [Chiralpak IB column], 70.0\% $n$ -

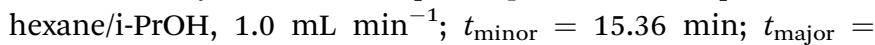
$33.13 \mathrm{~min} ; \lambda=254 \mathrm{~nm} ; 87 \%$ ee; $[\alpha]_{\mathrm{D}}^{20}=+11.08^{\circ}\left(c 0.05, \mathrm{CH}_{3} \mathrm{OH}\right)$; [ref. $\left.97[\alpha]_{\mathrm{D}}^{24}=+32.2^{\circ}(c 1.0, \mathrm{MeOH})\right] ;{ }^{1} \mathrm{H}-\mathrm{NMR}(500 \mathrm{MHz}, \mathrm{DMSO}-$ $\left.d_{6}\right): \delta(\mathrm{ppm})=10.23(\mathrm{~s}, 1 \mathrm{H}, \mathrm{NH}), 7.15\left(\mathrm{~s}, 2 \mathrm{H}, \mathrm{NH}_{2}\right), 6.75(\mathrm{dd}, J=$ 8.4, $2.6 \mathrm{~Hz}, 1 \mathrm{H}, \mathrm{Ar}-\mathrm{H}), 6.70(\mathrm{~d}, J=8.4 \mathrm{~Hz}, 1 \mathrm{H}, \mathrm{Ar}-\mathrm{H}), 6.68(\mathrm{~d}, J=$ $2.6 \mathrm{~Hz}, 1 \mathrm{H}, \mathrm{Ar}-\mathrm{H}), 3.80-3.76\left(\mathrm{~m}, 2 \mathrm{H}, \mathrm{CH}_{2} \mathrm{CH}_{3}\right), 3.67(\mathrm{~s}, 3 \mathrm{H}$, $\left.\mathrm{OCH}_{3}\right), 2.32\left(\mathrm{~s}, 3 \mathrm{H}, \mathrm{CH}_{3}\right), 0.80\left(\mathrm{t}, J=7.1 \mathrm{~Hz}, 3 \mathrm{H}, \mathrm{CH}_{2} \mathrm{CH}_{3}\right) ;{ }^{13} \mathrm{C}-$ NMR (126 MHz, DMSO- $\left.d_{6}\right): \delta(\mathrm{ppm})=178.56,164.55,158.93$, 158.67, 155.11, 135.90, 135.47, 117.60, 113.17, 110.28, 109.75, $104.56,60.30,56.60,55.48,49.46,18.65,13.05$. All the analytical data are well in agreement with the reported literature. ${ }^{97}$

Ethyl-(S)-2' -amino-3'-cyano-6'-methyl-5-nitro-2-oxospiro[indoline-3,4'-pyran]-5'-carboxylate (6f). 5-Nitroisatin $\mathbf{1 f}(38.4 \mathrm{mg}, 0.2$ $\mathrm{mmol})$, malononitrile $4(13.2 \mathrm{mg}, 0.2 \mathrm{mmol})$ and ethylacetoacetate $5(26.0 \mathrm{mg}, 0.2 \mathrm{mmol})$ were reacted according to the GP2 to yield product 6 f as white solid; m.p.: $253-254{ }^{\circ} \mathrm{C}$; isolated yield (65.9 $\mathrm{mg}, 89 \%$ ). Enantiomeric excess (ee) was determined by chiral HPLC [Daicel Chiralpak AD-H column], $90.0 \% n$-hexane $/ \mathrm{i}$-PrOH, $0.8 \mathrm{~mL} \mathrm{~min}^{-1} ; t_{\text {minor }}=61.83 \mathrm{~min} ; t_{\text {major }}$ $=64.37 \mathrm{~min} ; \lambda=254 \mathrm{~nm} ; 80 \%$ ee; $[\alpha]_{\mathrm{D}}^{20}=+16.51^{\circ}$ (c 0.05 , $\mathrm{CH}_{3} \mathrm{OH}$ ); IR (KBr): 3391, 3314, 3204, 2207, 1724, 1653, 1626, 1594, 1558, 1522, 1471, 1456, 1404, 1378, 1340, 1283, 1253, 1224, 1177, 1129, 1078, 844, 802, 756, 739, 690, 634, $557 \mathrm{~cm}^{-1}$; ${ }^{1} \mathrm{H}-\mathrm{NMR}\left(500 \mathrm{MHz}, \mathrm{DMSO}-d_{6}\right): \delta(\mathrm{ppm})=11.18(\mathrm{~s}, 1 \mathrm{H}, \mathrm{NH}), 8.19$ (dd, $J=8.6,2.4 \mathrm{~Hz}, 1 \mathrm{H}, \mathrm{Ar}-\mathrm{H}), 8.05$ (d, $J=2.4 \mathrm{~Hz}, 1 \mathrm{H}, \mathrm{Ar}-\mathrm{H}$ ), $7.37\left(\mathrm{~s}, 2 \mathrm{H}, \mathrm{NH}_{2}\right), 7.03(\mathrm{~d}, J=8.6 \mathrm{~Hz}, 1 \mathrm{H}, \mathrm{Ar}-\mathrm{H}), 3.86-3.78(\mathrm{~m}$, $\left.2 \mathrm{H}, \mathrm{CH}_{2} \mathrm{CH}_{3}\right), 2.38\left(\mathrm{~s}, 3 \mathrm{H}, \mathrm{CH}_{3}\right), 0.84\left(\mathrm{t}, J=7.1 \mathrm{~Hz}, 3 \mathrm{H}, \mathrm{CH}_{2} \mathrm{CH}_{3}\right)$; ${ }^{13} \mathrm{C}-\mathrm{NMR}\left(126 \mathrm{MHz}, \mathrm{DMSO}-d_{6}\right): \delta(\mathrm{ppm})=179.22,164.26$, $160.59,159.04,148.62$, 142.50, 136.05, 126.09, 119.20, 117.26, 109.63, 103.00, 60.66, 55.18, 49.21, 19.02, 13.12 .

Ethyl-(S)-2'-amino-5,7-dibromo-3'-cyano-6'-methyl-2-oxospiro [indoline-3,4'-pyran]-5'-carboxylate (6g). 5,7-Dibromoisatin $\mathbf{1 g}$ (61.0 mg, $0.2 \mathrm{mmol})$, malononitrile $4(13.2 \mathrm{mg}, 0.2 \mathrm{mmol})$ and ethylacetoacetate $5(26.0 \mathrm{mg}, 0.2 \mathrm{mmol})$ were reacted according to the GP2 to yield product $6 \mathrm{~g}$ as white solid; m.p.: $250-251{ }^{\circ} \mathrm{C}$; isolated yield (92.8 mg, 96\%). Enantiomeric excess (ee) was determined by chiral HPLC [Daicel Chiralpak AD-H column], $90.0 \% n$-hexane/i-PrOH, $0.8 \mathrm{~mL} \mathrm{~min}^{-1} ; t_{\text {minor }}=20.53 \mathrm{~min} ; t_{\text {major }}$ $=31.65 \mathrm{~min} ; \lambda=254 \mathrm{~nm} ; 50 \%$ ee; $[\alpha]_{\mathrm{D}}^{20}=+14.56^{\circ}$ (c 0.04 , $\mathrm{CH}_{3} \mathrm{OH}$ ); IR (KBr): 3479, 3296, 3160, 3066, 2980, 2197, 1723, 1710, 1677, 1610, 1596, 1584, 1459, 1409, 1302, 1288, 1253, $1213,1161,1129,1080,779,762,744,664,867,464 \mathrm{~cm}^{-1} ;{ }^{1} \mathrm{H}-$ NMR (500 MHz, DMSO- $\left.d_{6}\right): \delta(\mathrm{ppm})=10.94(\mathrm{~s}, 1 \mathrm{H}, \mathrm{NH}), 7.65$ (s, 1H, Ar-H), 7.39 (s, 1H, Ar-H), 7.35 (s, 2H, $\mathrm{NH}_{2}$ ), 3.83 (q, $J=$ $\left.9.3 \mathrm{~Hz}, 2 \mathrm{H}, \mathrm{CH}_{2} \mathrm{CH}_{3}\right), 2.35\left(\mathrm{~s}, 3 \mathrm{H}, \mathrm{CH}_{3}\right), 0.86(\mathrm{t}, J=7.1 \mathrm{~Hz}, 3 \mathrm{H}$, $\left.\mathrm{CH}_{2} \mathrm{CH}_{3}\right) ;{ }^{13} \mathrm{C}-\mathrm{NMR}\left(126 \mathrm{MHz}, \mathrm{DMSO}-d_{6}\right): \delta(\mathrm{ppm})=178.34$, 164.23 , 160.20, 158.90, 141.15, 138.39, 133.18, 125.69, 117.32, 114.05, 103.26, 102.68, 60.62, 55.46, 50.40, 18.92, 13.01.

Ethyl-(S)-2'-amino-3'-cyano-5, 6'-dimethyl-2-oxospiro[indoline3,4'-pyran]-5'-carboxylate (6h). 5-Methylisatin $\mathbf{1 h}(32.2 \mathrm{mg}, 0.2$ $\mathrm{mmol})$, malononitrile $4(13.2 \mathrm{mg}, 0.2 \mathrm{mmol})$ and ethylacetoacetate $5(26.0 \mathrm{mg}, 0.2 \mathrm{mmol})$ were reacted according to the GP2 to yield product $6 \mathbf{h}$ as white solid; m.p.: $255-256{ }^{\circ} \mathrm{C}$; isolated yield $(65.8 \mathrm{mg}, 97 \%)$. Enantiomeric excess (ee) was determined by chiral HPLC [Daicel Chiralpak AD-H column], $90.0 \% n$-hexane $/ \mathrm{i}$-PrOH, $0.8 \mathrm{~mL} \mathrm{~min}^{-1} ; t_{\text {minor }}=41.56 \mathrm{~min} ; t_{\text {major }}$ $=42.89 \mathrm{~min} ; \lambda=220 \mathrm{~nm} ; 95 \%$ ee; $[\alpha]_{\mathrm{D}}^{20}=-26.47^{\circ}$ (c 0.06 , $\left.\mathrm{CH}_{3} \mathrm{OH}\right) ;\left[\right.$ ref. $97[\alpha]_{\mathrm{D}}^{24}=-24.0^{\circ}\left(c\right.$ 1.0, MeOH)]; ${ }^{1} \mathrm{H}-\mathrm{NMR}(500$ MHz, DMSO- $\left.d_{6}\right): \delta(\mathrm{ppm})=10.28(\mathrm{~s}, 1 \mathrm{H}, \mathrm{NH}), 7.11\left(\mathrm{~s}, 2 \mathrm{H}, \mathrm{NH}_{2}\right)$, $6.97(\mathrm{~d}, J=8.6 \mathrm{~Hz}, 1 \mathrm{H}, \mathrm{Ar}-\mathrm{H}), 6.87$ (s, 1H, Ar-H), 6.68 (d, $J=$ $7.9 \mathrm{~Hz}, 1 \mathrm{H}, \mathrm{Ar}-\mathrm{H}), 3.78$ (q, $\left.J=7.1 \mathrm{~Hz}, 2 \mathrm{H}, \mathrm{CH}_{2} \mathrm{CH}_{3}\right), 2.31$ (s, $3 \mathrm{H}$, $\left.\mathrm{CH}_{3}\right), 0.80\left(\mathrm{t}, \mathrm{J}=7.1 \mathrm{~Hz}, 3 \mathrm{H}, \mathrm{CH}_{2} \mathrm{CH}_{3}\right) ;{ }^{13} \mathrm{C}-\mathrm{NMR}(126 \mathrm{MHz}$, DMSO- $\left.d_{6}\right): \delta(\mathrm{ppm})=178.58,164.55,158.88,158.51,139.66$, 134.73, 130.67, 128.78, 123.94, 117.57, 109.07, 104.71, 60.27, $56.75,49.02,20.63,18.61,13.00$. All the analytical data are well in agreement with the reported literature. ${ }^{97}$

Ethyl-(S)-2'-amino-3'-cyano-5-fluoro-6'-methyl-2-oxospiro[indoline-3,4'-pyran]-5'-carboxylate (6i). 5-Fluoroisatin $1 \mathbf{i}(33.0 \mathrm{mg}, 0.2$ mmol), malononitrile $4(13.2 \mathrm{mg}, 0.2 \mathrm{mmol})$ and ethylacetoacetate $5(26.0 \mathrm{mg}, 0.2 \mathrm{mmol})$ were reacted according to the GP2 to yield product $\mathbf{6 i}$ as white solid; m.p.: $253-254{ }^{\circ} \mathrm{C}$; isolated yield (65.9 mg, 98\%). Enantiomeric excess (ee) was determined by chiral HPLC [Daicel Chiralpak AD-H column], $90.0 \% n$-hexane $/ \mathrm{i}$-PrOH, $0.8 \mathrm{~mL} \mathrm{~min}^{-1} ; t_{\text {major }}=39.61 \mathrm{~min} ; t_{\text {minor }}$ $=43.67 \mathrm{~min} ; \lambda=220 \mathrm{~nm} ; 39 \%$ ee; $[\alpha]_{\mathrm{D}}^{20}=-23.38^{\circ}(c 0.08$, $\left.\mathrm{CH}_{3} \mathrm{OH}\right) ;\left[\right.$ ref. $97[\alpha]_{\mathrm{D}}^{24}=-18.9^{\circ}\left(c\right.$ 1.0, MeOH)]; ${ }^{1} \mathrm{H}-\mathrm{NMR}(500$ MHz, DMSO- $\left.d_{6}\right): \delta(\mathrm{ppm})=10.44(\mathrm{~s}, 1 \mathrm{H}, \mathrm{NH}), 7.23\left(\mathrm{~s}, 2 \mathrm{H}, \mathrm{NH}_{2}\right)$, 7.07-6.96 (m, 2H, Ar-H), 6.78 (dd, $J=8.5,4.3 \mathrm{~Hz}, 1 \mathrm{H}, \mathrm{Ar}-\mathrm{H})$, 3.87-3.73 (m, 2H, $\left.\mathrm{CH}_{2} \mathrm{CH}_{3}\right), 2.32\left(\mathrm{~s}, 3 \mathrm{H}, \mathrm{CH}_{3}\right), 0.82(\mathrm{t}, J=7.1 \mathrm{~Hz}$, $\left.3 \mathrm{H}, \mathrm{CH}_{2} \mathrm{CH}_{3}\right) ;{ }^{13} \mathrm{C}-\mathrm{NMR}\left(126 \mathrm{MHz}, \mathrm{DMSO}-d_{6}\right): \delta(\mathrm{ppm})=178.72$, 164.42 , 159.29, 159.20, 158.97, 157.31, 138.36, 136.48, 136.43, $117.44,114.90,114.71,111.43,111.23,110.12$, 110.06, 103.97, $60.40,56.03,49.53,18.76,13.06$. All the analytical data are well in agreement with the reported literature. ${ }^{97}$

Ethyl-(S)-2'-amino-3'-cyano-1,6'-dimethyl-2-oxospiro[indoline3,4'-pyran]-5'-carboxylate (6j). 1-Methylisatin $\mathbf{1 j}(32.2 \mathrm{mg}, 0.2$ $\mathrm{mmol})$, malononitrile $4(13.2 \mathrm{mg}, 0.2 \mathrm{mmol})$ and ethylacetoacetate $5(26.0 \mathrm{mg}, 0.2 \mathrm{mmol})$ were reacted according to the GP2 to yield product $6 \mathbf{j}$ as white solid; m.p.: $=257-258{ }^{\circ} \mathrm{C}$, isolated yield (67.2 mg, 99\%). Enantiomeric excess (ee) was determined by chiral HPLC [Daicel Chiralpak AD-H column],

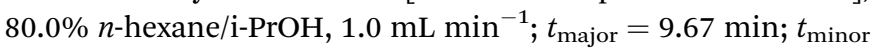
$=11.24 \mathrm{~min} ; \lambda=254 \mathrm{~nm} ; 63 \%$ ee; $[\alpha]_{\mathrm{D}}^{20}=+26.29^{\circ}(c 0.07$, $\left.\mathrm{CH}_{3} \mathrm{OH}\right) ;\left[\right.$ ref. $97[\alpha]_{\mathrm{D}}^{24}=+14.7^{\circ}(c$ 1.0, MeOH$\left.)\right] ;{ }^{1} \mathrm{H}-\mathrm{NMR}(500$ MHz, DMSO- $\left.d_{6}\right): \delta(\mathrm{ppm})=7.29(\mathrm{td}, J=7.7,1.4 \mathrm{~Hz}, 1 \mathrm{H}, \mathrm{Ar}-\mathrm{H})$, 7.20 (s, 2H, $\mathrm{NH}_{2}$ ), 7.12 (dd, $J=7.4,1.3 \mathrm{~Hz}, 1 \mathrm{H}, \mathrm{Ar}-\mathrm{H}$ ), 7.04-6.99 (m, 2H, Ar-H), 3.72 (q, $\left.J=3.0 \mathrm{~Hz}, 2 \mathrm{H}, \mathrm{CH}_{2}-\mathrm{CH}_{3}\right), 3.14(\mathrm{~s}, 3 \mathrm{H}$, $\left.\mathrm{NCH}_{3}\right), 2.33\left(\mathrm{~s}, 3 \mathrm{H}, \mathrm{CH}_{3}\right), 0.72\left(\mathrm{t}, J=7.1 \mathrm{~Hz}, 3 \mathrm{H}, \mathrm{CH}_{2} \mathrm{CH}_{3}\right) ;{ }^{13} \mathrm{C}-$ NMR (126 MHz, DMSO- $\left.d_{6}\right): \delta(\mathrm{ppm})=176.96,164.34,158.98$, $158.95,143.50,133.74,128.76,123.13$, 122.62, 117.33, 108.25, $104.41,60.19,56.15,48.51,26.30,18.62,13.19$. All the analytical data are well in agreement with the reported literature. ${ }^{97}$

Ethyl-(S)-2'-amino-1-benzyl-3'-cyano-6'-methyl-2-oxospiro[indoline-3,4'-pyran]-5'-carboxylate (6k). 1-Benzylisatin 1k (47.5 mg, $0.2 \mathrm{mmol})$, malononitrile $4(13.2 \mathrm{mg}, 0.2 \mathrm{mmol})$ and ethylacetoacetate $5(26.0 \mathrm{mg}, 0.2 \mathrm{mmol})$ were reacted according to the GP2 to yield product $6 \mathbf{k}$ as white solid; m.p.: $251-252{ }^{\circ} \mathrm{C}$; isolated yield (81.4 mg, 98\%). Enantiomeric excess (ee) was determined by chiral HPLC [Daicel Chiralpak AD-H column], $80.0 \% n$-hexane/i-PrOH, $1.0 \mathrm{~mL} \mathrm{~min}^{-1} ; t_{\text {major }}=12.33 \mathrm{~min} ; t_{\text {minor }}$ $=20.59 \mathrm{~min} ; \lambda=254 \mathrm{~nm} ; 81 \%$ ee; $[\alpha]_{\mathrm{D}}^{20}=+19.55^{\circ}(c \quad 0.06$, 
$\left.\mathrm{CH}_{3} \mathrm{OH}\right)$; [ref. $97[\alpha]_{\mathrm{D}}^{24}=+20.4^{\circ}\left(c\right.$ 1.0, MeOH)]; ${ }^{1} \mathrm{H}-\mathrm{NMR}(500$ MHz, DMSO- $\left.d_{6}\right): \delta(\mathrm{ppm})=7.48-7.45(\mathrm{~m}, 2 \mathrm{H}, \mathrm{Ar}-\mathrm{H}), 7.33-7.30$ $(\mathrm{m}, 2 \mathrm{H}, \mathrm{Ar}-\mathrm{H}), 7.28(\mathrm{~s}, 1 \mathrm{H}, \mathrm{Ar}-\mathrm{H}), 7.25\left(\mathrm{~s}, 2 \mathrm{H}, \mathrm{NH}_{2}\right), 7.20(\mathrm{td}, J=$ 7.7, $1.3 \mathrm{~Hz}, 1 \mathrm{H}, \mathrm{Ar}-\mathrm{H}), 7.15$ (dd, $J=7.4,1.3 \mathrm{~Hz}, 1 \mathrm{H}, \mathrm{Ar}-\mathrm{H}), 7.00$ $(\mathrm{td}, J=7.5,1.0 \mathrm{~Hz}, 1 \mathrm{H}, \mathrm{Ar}-\mathrm{H}), 6.86(\mathrm{~d}, J=7.7 \mathrm{~Hz}, 1 \mathrm{H}, \mathrm{Ar}-\mathrm{H}), 5.00$ $\left(\mathrm{d}, J=15.8 \mathrm{~Hz}, 1 \mathrm{H}, \mathrm{CH}_{2(\mathrm{a})} \mathrm{Bn}\right), 4.78(\mathrm{~d}, J=15.8 \mathrm{~Hz}, 1 \mathrm{H}$, $\left.\mathrm{CH}_{2(\mathrm{~b})} \mathrm{Bn}\right), 3.78\left(\mathrm{q}, J=7.1 \mathrm{~Hz}, 1 \mathrm{H}, \mathrm{CH}_{2} \mathrm{CH}_{3}\right), 3.52(\mathrm{dd}, J=10.8$, $\left.7.1 \mathrm{~Hz}, 1 \mathrm{H}, \mathrm{CH}_{2} \mathrm{CH}_{3}\right), 2.34\left(\mathrm{~s}, 3 \mathrm{H}, \mathrm{CH}_{3}\right), 0.58(\mathrm{t}, J=7.1 \mathrm{~Hz}, 3 \mathrm{H}$, $\left.\mathrm{CH}_{2} \mathrm{CH}_{3}\right) ;{ }^{13} \mathrm{C}-\mathrm{NMR}\left(126 \mathrm{MHz}\right.$, DMSO- $\left.d_{6}\right): \delta(\mathrm{ppm})=177.20$, 164.38, 159.19, 158.86, 142.77, 136.19, 133.65, 128.40, 127.55, 123.34, 122.73, 117.57, 108.91, 104.55, 60.11, 56.12, 48.52, $43.39,18.65,13.08$. All the analytical data are well in agreement with the reported literature. ${ }^{97}$

Ethyl-(S)-2'-amino-1-(2-bromoethyl)-3'-cyano-6'-methyl-2-oxospiro[indoline-3,4'-pyran]-5'-carboxylate (6l). 1-(2-Bromoethyl) isatin $11(50.8 \mathrm{mg}, 0.2 \mathrm{mmol})$, malononitrile $4(13.2 \mathrm{mg}, 0.2$ $\mathrm{mmol})$ and ethylacetoacetate $5(26.0 \mathrm{mg}, 0.2 \mathrm{mmol})$ were reacted according to the GP2 to yield product $\mathbf{6 1}$ as white solid; m.p.: $148-150{ }^{\circ} \mathrm{C}$; isolated yield $(76.9 \mathrm{mg}, 89 \%)$. Enantiomeric excess (ee) was determined by chiral HPLC [Daicel Chiralpak AD-H

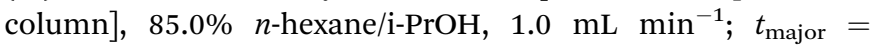
$15.03 \mathrm{~min} ; t_{\text {minor }}=24.53 \mathrm{~min} ; \lambda=254 \mathrm{~nm} ; 23 \%$ ee; $[\alpha]_{\mathrm{D}}^{20}=$ $+5.34^{\circ}$ (c 0.10, $\left.\mathrm{CH}_{3} \mathrm{OH}\right)$; IR (KBr): 3382, 2924, 2854, 2191, 1709, 1682, 1613, 1599, 1486, 1466, 1419, 1380, 1348, 1282, 1253, $1211,1149,1077,756,682 \mathrm{~cm}^{-1} ;{ }^{1} \mathrm{H}-\mathrm{NMR}\left(500 \mathrm{MHz}\right.$, DMSO- $\left.d_{6}\right)$ : $\delta(\mathrm{ppm})=7.29(\mathrm{td}, J=7.6,1.3 \mathrm{~Hz}, 1 \mathrm{H}, \mathrm{Ar}-\mathrm{H}), 7.23\left(\mathrm{~s}, 2 \mathrm{H}, \mathrm{NH}_{2}\right)$, 7.18-7.13 (m, 2H, Ar-H), 7.03 (td, $J=7.5,1.0 \mathrm{~Hz}, 1 \mathrm{H}, \mathrm{Ar}-\mathrm{H}), 4.16$ (ddd, $\left.J=14.2,7.7,6.5 \mathrm{~Hz}, 1 \mathrm{H}, \mathrm{CH}_{3} \mathrm{CH}_{2(\mathrm{a})}\right), 4.03(\mathrm{ddd}, J=14.2$, $\left.7.7,6.1 \mathrm{~Hz}, 1 \mathrm{H}, \mathrm{CH}_{3} \mathrm{CH}_{2(\mathrm{~b})}\right), 3.82(\mathrm{dq}, J=11.0,7.1 \mathrm{~Hz}, 1 \mathrm{H}$, $\left.\mathrm{NCH}_{2(\mathrm{a})}\right), 3.72$ (qd, $\left.J=7.1,4.6 \mathrm{~Hz}, 1 \mathrm{H}, \mathrm{NCH}_{2(\mathrm{~b})}\right), 3.63-3.57$ (m, $\left.2 \mathrm{H}, \mathrm{CH}_{2} \mathrm{Br}\right), 2.33\left(\mathrm{~s}, 3 \mathrm{H}, \mathrm{CH}_{3}\right), 0.71\left(\mathrm{t}, J=7.1 \mathrm{~Hz}, 3 \mathrm{H}, \mathrm{CH}_{2} \mathrm{CH}_{3}\right)$; ${ }^{13} \mathrm{C}-\mathrm{NMR}\left(126 \mathrm{MHz}\right.$, DMSO- $\left.d_{6}\right): \delta(\mathrm{ppm})=177.03,164.32$, 158.99, 142.18, 133.54, 128.76, 123.41, 122.84, 117.14, 108.70, 104.36, 60.25, 56.08, 48.41, 41.57, 28.36, 18.67, 13.22.

\section{Conclusions}

In summary, we have developed very efficient enantioselective process for the asymmetric Aldol reaction of substituted isatin with several acetone derivatives using $\mathbf{L 1}-\mathrm{Cu}$ (II) as a new Lewis acid catalyst based on thiophene-2,5-bis(amino-alcohol) framework. Our Lewis acid catalytic system L1-Cu(II) acts brilliantly and furnished aldol products 3a-s in high yields and selectivity (up to $99 \%$ yield; up to $96 \%$ ee). This catalytic system L1- $\mathrm{Cu}(\mathrm{OAc})_{2} \cdot \mathrm{H}_{2} \mathrm{O}$ was further utilized for asymmetric Domino Knoevenagel Michael cyclization reaction of substituted isatin with malononitrile and ethylacetoacetate and afforded chiral spiro[4H-pyran-3,3-oxindole] derivatives 6a-1 with high yields and moderate to high enantioselectivities (up to $99 \%$ yield; up to $95 \%$ ee). Both the reactions were performed under mild reaction condition at room temperature.

\section{Author contributions}

Conceptualization, A. M. A.-M. and A. B.; supervision, A. M. A.M., A. B. and M. S. I; methodology, A. S. A., M. S. I. and A. M. A.M.; validation, M. S. I., A. S. A., S. A. and A. M. A.-M.; formal analysis, A. S. A.; M. S. I. and S. A.; investigation, A. S. A.; M. S. I. and S. A.; resources, A. M. A.-M. and A. B.; data curation, A. S. A., M. S. I., and A. B.; writing-original draft preparation, M. S. I., A. B. and A. S. A.; writing-review and editing, M. S. I., A. B. and A. M. A.-M.; visualization, A. B., M. S. I and S. A.; project administration, A. M. A.-M. and A. B.; funding acquisition, A. M. A.-M. and A. B.; software A. S. A., M. S. I., M. A. and A. B.; all authors have read and agreed to the published version of the manuscript.

\section{Conflicts of interest}

There are no conflicts to declare.

\section{Acknowledgements}

The authors would like to extend their sincere appreciation to the Researchers Supporting Project (RSP2022R427), King Saud University, Riyadh, Saudi Arabia.

\section{Notes and references}

1 P. W. V. Leeuwen, P. C. Kamer, C. Claver, O. Pamies and M. Dieguez, Chem. Rev., 2011, 111, 2077-2118.

2 A. Barakat, M. S. Islam, A. M. Al Majid and Z. A. Al-Othman, Tetrahedron, 2013, 69, 5185-5192.

3 M. S. Islam, A. M. Al Majid, Z. A. Al-Othman and A. Barakat, Tetrahedron: Asymmetry, 2014, 25, 245-251.

4 M. S. Islam, A. S. Alammari, A. Barakat, S. Alshahrani, M. Haukka and A. M. Al-Majid, Molecules, 2021, 26, 7408.

5 A. S. Alammari, A. M. Al-Majid, A. Barakat, S. Alshahrani, M. Ali and M. S. Islam, Catalysts, 2021, 11, 1208.

6 T. Mukaiyama, Org. React., 1982.

7 Q. Guo, M. Bhanushali and C. G. Zhao, Angew. Chem., Int. Ed., 2010, 49, 9460-9464.

8 T. Yan, X. Wang, H. Sun, J. Liu and Y. Xie, Molecules, 2013, 18, 14505-14518.

9 V. Kumar, K. Kaur, G. K. Gupta and A. K. Sharma, Eur. J. Med. Chem., 2013, 69, 735-753.

10 V. Raj, Int. J. Curr. Pharm. Res., 2012, 4, 1-9.

11 C. Marti and E. M. Carreira, Eur. J. Org. Chem., 2003, 2003, 2209-2219.

12 C. V. Galliford and K. A. Scheidt, Angew. Chem., Int. Ed., 2007, 46, 8748-8758.

13 S. Peddibhotla, Curr. Bioact. Compd., 2009, 5, 20-38.

14 S. Mohammadi, R. Heiran, R. P. Herrera and E. MarquesLopez, ChemCatChem, 2013, 5, 2131-2148.

15 R. B. Labroo and L. A. Cohen, J. Org. Chem., 1990, 55, 49014904.

16 P. Hewawasam, N. A. Meanwell, V. K. Gribkoff, S. I. Dworetzky and C. G. Boissard, Bioorg. Med. Chem. Lett., 1997, 7, 1255-1260.

17 Y. Q. Tang, I. Sattler, R. Thiericke, S. Grabley and X. Z. Feng, Eur. J. Org. Chem., 2001, 2001, 261-267.

18 T. Tokunaga, W. E. Hume, T. Umezome, K. Okazaki, Y. Ueki, K. Kumagai, S. Hourai, J. Nagamine, H. Seki and M. Taiji, J. Med. Chem., 2001, 44, 4641-4649. 
19 P. Hewawasam, M. Erway, S. L. Moon, J. Knipe, H. Weiner, C. G. Boissard, D. J. Post-Munson, Q. Gao, S. Huang and V. K. Gribkoff, J. Med. Chem., 2002, 45, 1487-1499.

20 V. Khuzhaev, I. Zhalolov, K. Turgunov, B. Tashkhodzhaev, M. Levkovich, S. Aripova and A. Shashkov, Chem. Nat. Compd., 2004, 40, 269-272.

21 H. B. Rasmussen and J. K. MacLeod, J. Nat. Prod., 1997, 60, 1152-1154.

22 T. Kagata, S. Saito, H. Shigemori, A. Ohsaki, H. Ishiyama, T. Kubota and J. i. Kobayashi, J. Nat. Prod., 2006, 69, 1517-1521.

23 Y. Kamano, H.-p. Zhang, Y. Ichihara, H. Kizu, K. Komiyama and G. R. Pettit, Tetrahedron Lett., 1995, 36, 2783-2784.

24 C. Moody, I. Richards and A. Z. Slawin, J. Chem. Soc., Perkin Trans. 1, 1997, 2405-2412.

25 T. Nakamura, S.-i. Shirokawa, S. Hosokawa, A. Nakazaki and S. Kobayashi, Org. Lett., 2006, 8, 677-679.

26 S. Nakamura, N. Hara, H. Nakashima, K. Kubo, N. Shibata and T. Toru, Chem.-Eur. J., 2008, 14, 8079-8081.

27 G. Luppi, M. Monari, R. J. Corrêa, F. d. A. Violante, A. C. Pinto, B. Kaptein, Q. B. Broxterman, S. J. Garden and C. Tomasini, Tetrahedron, 2006, 62, 12017-12024.

28 J. S. Carle and C. Christophersen, J. Org. Chem., 1981, 46, 3440-3443.

29 K. Nicolaou, X. Huang, N. Giuseppone, P. Bheema Rao, M. Bella, M. V. Reddy and S. A. Snyder, Angew. Chem., Int. Ed., 2001, 40, 4705-4709.

30 K. Nicolaou, M. Bella, D. Y. K. Chen, X. Huang, T. Ling and S. A. Snyder, Angew. Chem., Int. Ed., 2002, 114, 3645-3649.

31 K. Nicolaou, P. Bheema Rao, J. Hao, M. V. Reddy, G. Rassias, X. Huang, D. Y. K. Chen and S. A. Snyder, Angew. Chem., Int. Ed., 2003, 42, 1753-1758.

32 K. Nicolaou, S. A. Snyder, N. Giuseppone, X. Huang, M. Bella, M. V. Reddy, P. B. Rao, A. E. Koumbis, P. Giannakakou and A. O'Brate, J. Am. Chem. Soc., 2004, 126, 10174-10182.

33 K. Nicolaou, D. Y.-K. Chen, X. Huang, T. Ling, M. Bella and S. A. Snyder, J. Am. Chem. Soc., 2004, 126, 12888-12896.

34 C. Takahashi, A. Numata, Y. Ito, E. Matsumura, H. Araki, H. Iwaki and K. Kushida, J. Chem. Soc., Perkin Trans. 1, 1994, 1859-1864.

35 A. Fréchard, N. Fabre, C. Péan, S. Montaut, M.-T. Fauvel, P. Rollin and I. Fourasté, Tetrahedron Lett., 2001, 42, 9015-9017.

36 M. Kitajima, I. Mori, K. Arai, N. Kogure and H. Takayama, Tetrahedron Lett., 2006, 47, 3199-3202.

37 J. I. Jimenez, U. Huber, R. E. Moore and G. M. Patterson, J. Nat. Prod., 1999, 62, 569-572.

38 B. K. Albrecht and R. M. Williams, Org. Lett., 2003, 5, 197200.

39 S. Lin, Z.-Q. Yang, B. H. Kwok, M. Koldobskiy, C. M. Crews and S. J. Danishefsky, J. Am. Chem. Soc., 2004, 126, 63476355.

40 K. S. Feldman and A. G. Karatjas, Org. Lett., 2004, 6, 28492852.

41 H. Suzuki, H. Morita, M. Shiro and J. i. Kobayashi, Tetrahedron, 2004, 60, 2489-2495.
42 M. Suchý, P. Kutschy, K. Monde, H. Goto, N. Harada, M. Takasugi, M. Dzurilla and E. Balentova, J. Org. Chem., 2001, 66, 3940-3947.

43 F. Zhou, Y. L. Liu and J. Zhou, Adv. Synth. Catal., 2010, 352, 1381-1407.

44 J. J. Badillo, N. V. Hanhan and A. K. Franz, Curr. Opin. Drug Discovery Dev., 2010, 13, 758-776.

45 A. Kumar and S. S. Chimni, RSC Adv., 2012, 2, 9748-9762.

46 B. Alcaide and P. Almendros, Angew. Chem., Int. Ed., 2003, 42, 858-860.

47 B. List, L. Hoang and H. J. Martin, Proc. Natl. Acad. Sci. U. S. A., 2004, 101, 5839-5842.

48 C. Allemann, R. Gordillo, F. R. Clemente, P. H.-Y. Cheong and K. Houk, Acc. Chem. Res., 2004, 37, 558-569.

49 S. Saito and H. Yamamoto, Acc. Chem. Res., 2004, 37, 570579.

50 S. M. Dean, W. A. Greenberg and C. H. Wong, Adv. Synth. Catal., 2007, 349, 1308-1320.

51 M. Raj and V. K. Singh, Chem. Commun., 2009, 6687-6703.

52 V. Bisai, A. Bisai and V. K. Singh, Tetrahedron, 2012, 68, 4541-4580.

53 B. List, R. A. Lerner and C. F. Barbas, J. Am. Chem. Soc., 2000, 122, 2395-2396.

54 A. Spek, Acta Crystallogr., Sect. D: Biol. Crystallogr., 2009, 65, 148-155.

55 G. Luppi, P. G. Cozzi, M. Monari, B. Kaptein, Q. B. Broxterman and C. Tomasini, J. Org. Chem., 2005, 70, 7418-7421.

56 E. M. Beccalli, A. Marchesini and T. Pilati, J. Chem. Soc., Perkin Trans. 1, 1994, 579-587.

57 S. J. Garden, R. B. da Silva and A. C. Pinto, Tetrahedron, 2002, 58, 8399-8412.

58 T. Kawasaki, M. Nagaoka, T. Satoh, A. Okamoto, R. Ukon and A. Ogawa, Tetrahedron, 2004, 60, 3493-3503.

59 W.-B. Chen, Y.-H. Liao, X.-L. Du, X.-M. Zhang and W.-C. Yuan, Green Chem., 2009, 11, 1465-1476.

60 R. J. Corrêa, S. J. Garden, G. Angelici and C. Tomasini, Eur. J. Org. Chem., 2008, 2008, 736-744.

61 G. Angelici, R. J. Corrêa, S. J. Garden and C. Tomasini, Tetrahedron Lett., 2009, 50, 814-817.

62 J. G. Hernández, V. García-López and E. Juaristi, Tetrahedron, 2012, 68, 92-97.

63 M. Kinsella, P. G. Duggan and C. M. Lennon, Tetrahedron: Asymmetry, 2011, 22, 1423-1433.

64 J.-R. Chen, X.-P. Liu, X.-Y. Zhu, L. Li, Y.-F. Qiao, J.-M. Zhang and W.-J. Xiao, Tetrahedron, 2007, 63, 10437-10444.

65 C. Shen, F. Shen, H. Xia, P. Zhang and X. Chen, Tetrahedron: Asymmetry, 2011, 22, 708-712.

66 T. P. Kumar, N. Manjula and K. Katragunta, Tetrahedron: Asymmetry, 2015, 26, 1281-1284.

67 G. D. Yadav and S. Singh, Tetrahedron: Asymmetry, 2016, 27, 123-129.

68 A. J. Pearson and S. Panda, Org. Lett., 2011, 13, 5548-5551.

69 G. D. Yadav and S. Singh, Tetrahedron: Asymmetry, 2015, 26, 1156-1166.

70 N. Hara, S. Nakamura, N. Shibata and T. Toru, Adv. Synth. Catal., 2010, 352, 1621-1624. 
71 N. Hara, S. Nakamura, N. Shibata and T. Toru, Chem.-Eur. J., 2009, 15, 6790-6793.

72 J. Wang, Q. Liu, Q. Hao, Y. Sun, Y. Luo and H. Yang, Chirality, 2015, 27, 314-319.

73 M. Raj, N. Veerasamy and V. K. Singh, Tetrahedron Lett., 2010, 51, 2157-2159.

74 Q. Guo and J. C.-G. Zhao, Tetrahedron Lett., 2012, 53, 17681771.

75 D. Ma, L. Ren, H. Yao, W. Tian, F. Chen, J. Zhang, Y. Liu and T. Mao, J. Orthop. Res., 2013, 31, 1082-1088.

76 H. Lu, J. Bai, J. Xu, T. Yang, X. Lin, J. Li and F. Ren, Tetrahedron, 2015, 71, 2610-2615.

77 S. Abbaraju and J. C. G. Zhao, Adv. Synth. Catal., 2014, 356, 237-241.

78 A. V. Malkov, M. A. Kabeshov, M. Bella, O. Kysilka, D. A. Malyshev, K. Pluháčková and P. Kočovský, Org. Lett., 2007, 9, 5473-5476.

79 Z.-Q. Liu, Z.-W. Xiang, Z. Shen, Q. Wu and X.-F. Lin, Biochimie, 2014, 101, 156-160.

80 T. Itoh, H. Ishikawa and Y. Hayashi, Org. Lett., 2009, 11, 3854-3857.

81 G. Chen, Y. Ju, T. Yang, Z. Li, W. Ang, Z. Sang, J. Liu and Y. Luo, Tetrahedron: Asymmetry, 2015, 26, 943-947.

82 R. Singh and R. Vince, Chem. Rev., 2012, 112, 4642-4686.

83 Y.-T. Yang, J.-F. Zhu, G. Liao, H.-J. Xu and B. Yu, Curr. Med. Chem., 2018, 25, 2233-2244.

84 M. S. Islam, M. Ali, A. M. Al-Majid, A. S. Alamary, S. Alshahrani, S. Yousuf, M. I. Choudhary and A. Barakat, Molecules, 2021, 26, 2212.

85 M. S. Islam, A. M. Al-Majid, M. Azam, V. P. Verma, A. Barakat, M. Haukka, A. A. Elgazar, A. Mira and F. A. Badria, ACS Omega, 2021, 31539-31556.

86 M. S. Islam, A. M. Al-Majid, F. F. El-Senduny, F. A. Badria, A. Rahman, A. Barakat and Y. A. Elshaier, Appl. Sci., 2020, 10, 2170.
87 M. S. Islam, A. M. Al-Majid, M. Azam, V. Prakash Verma, A. Barakat, M. Haukka, L. R. Domingo, A. A. Elgazar, A. Mira and F. A. Badria, ChemistrySelect, 2021, 6, 1403914053.

88 A. Barakat, M. S. Islam, M. Ali, A. M. Al-Majid, S. Alshahrani, A. S. Alamary, S. Yousuf and M. I. Choudhary, Symmetry, 2021, 13, 1426.

89 A. M. Al-Majid, M. Ali, M. S. Islam, S. Alshahrani, A. S. Alamary, S. Yousuf, M. I. Choudhary and A. Barakat, Molecules, 2021, 26, 6305.

90 R. Dworczak, H. Sterk, C. Kratky and H. Junek, Chem. Ber., 1989, 122, 1323-1328.

91 S. J. Chai, Y. F. Lai, J. C. Xu, H. Zheng, Q. Zhu and P. F. Zhang, Adv. Synth. Catal., 2011, 353, 371-375.

92 G. Brahmachari and B. Banerjee, Asian J. Org. Chem., 2016, 5, 271-286.

93 D. Cheng, Y. Ishihara, B. Tan and C. F. Barbas III, ACS Catal., 2014, 4, 743-762.

94 G. M. Ziarani, R. Moradi and N. Lashgari, Tetrahedron, 2018, 74, 1323-1353.

95 W.-B. Chen, Z.-J. Wu, Q.-L. Pei, L.-F. Cun, X.-M. Zhang and W.-C. Yuan, Org. Lett., 2010, 12, 3132-3135.

96 M. Chennapuram, I. A. Owolabi, C. Seki, Y. Okuyama, E. Kwon, K. Uwai, M. Tokiwa, M. Takeshita and H. Nakano, ACS Omega, 2018, 3, 11718-11726.

97 S. Konda, S. Jakkampudi, H. D. Arman and J. C.-G. Zhao, Synth. Commun., 2019, 49, 2971-2982.

98 S. Lee and J. F. Hartwig, J. Org. Chem., 2001, 66, 3402-3415. 99 W.-J. Hao, S.-Y. Wang and S.-J. Ji, ACS Catal., 2013, 3, 25012504.

100 A. Khalafi-Nezhad and S. Mohammadi, ACS Comb. Sci., 2013, 15, 512-518.

101 A. Mondal and C. Mukhopadhyay, ACS Comb. Sci., 2015, 17, 404-408. 